\title{
A critical analysis of disease-associated DNA polymorphisms in the genes of cattle, goat, sheep, and pig
}

\author{
Eveline M. Ibeagha-Awemu $\cdot$ Patrick Kgwatalala \\ Aloysius E. Ibeagha $\cdot$ Xin Zhao
}

Received: 28 September 2007/ Accepted: 11 February 2008/Published online: 19 March 2008

(C) The Author(s) 2008

\begin{abstract}
Genetic variations through their effects on gene expression and protein function underlie disease susceptibility in farm animal species. The variations are in the form of single nucleotide polymorphisms, deletions/insertions of nucleotides or whole genes, gene or whole chromosomal rearrangements, gene duplications, and copy number polymorphisms or variants. They exert varying degrees of effects on gene action, such as substitution of an amino acid for another, shift in reading frame and premature termination of translation, and complete deletion of entire exon(s) or gene(s) in diseased individuals. These factors influence gene function by affecting mRNA splicing pattern or by altering/ eliminating protein function. Elucidating the genetic bases of diseases under the control of many genes is very challenging, and it is compounded by several factors, including host $x$ pathogen $x$ environment interactions. In this review, the genetic variations that underlie several diseases of livestock (under monogenic and polygenic control) are analyzed. Also, factors hampering research efforts toward identification of genetic influences on animal disease identification and control are highlighted. A better understanding of the factors analyzed could be better harnessed to effectively identify and control, genetically, livestock diseases. Finally, genetic control of animal diseases can reduce the costs
\end{abstract}

E. M. Ibeagha-Awemu - P. Kgwatalala · A. E. Ibeagha .

X. Zhao ( ()

Department of Animal Science, McGill University,

21,111 Lakeshore Road, Ste Anne De Bellevue, Montreal,

QC, Canada H9X 3V9

e-mail: xin.zhao@mcgill.ca

E. M. Ibeagha-Awemu

e-mail: Eveline.ibeagha-awemu@mcgill.ca

E. M. Ibeagha-Awemu

e-mail: Eveline.ibeagha-awemu@mcgill.ca associated with diseases, improve animal welfare, and provide healthy animal products to consumers, and should be given more attention.

\section{Introduction}

Since the unraveling of the genetic material and the rapid development of molecular genetic tools, the last 50 years has witnessed a tremendous growth in the knowledge base and exploitation of genetic information in tackling human and animal diseases. The genetic material in farm animal species harbors a rich collection of genetic variations with either useful or harmful consequences on health and productivity. These variations are usually in the form of single nucleotide polymorphisms (SNPs), deletions/insertions of nucleotides or whole genes, gene or whole chromosomal rearrangements, gene duplications, copy number polymorphisms (e.g., variable number of tandem repeats and microsatellites), copy number variations (represents a copy number change involving a DNA fragment that is $1 \mathrm{~kb}$ or larger [Feuk et al. 2006]), and presence/absence of transposable elements (e.g., Alu elements). Although these variations constitute just a small percentage of the genome $(<1 \%$ in humans; Check 2005), they form the basis of biodiversity or individual variability in response to environmental stimuli. They could be found in both the coding and the regulatory regions of genes with the ability to modify gene function or expression and therefore may result in undesirable conditions, like diseases.

Compared to the human genome and with the exception of the Bos taurus genome which is now about $95 \%$ complete, sequencing of the genome of some farm animal species like the goat, pig, and sheep is still in the initial or 
planning stages. With the available genome information, however, there is an explosion of information in studies relating to genome variation and various aspects of disease, production, and adaptation. However, genome research in relation to diseases in farm animals is less intense and also differs in several respects from that in humans. The main focus of research into the genetic basis of animal diseases is the prospect of increasing productivity for human benefit or using such as models for human disease research. The attention now is also being directed toward breeding for disease resistance. Effective exploitation of disease-resistant livestock or complete elimination of diseased livestock must be backed by knowledge of the genes, the causal mutations, and interactions with other factors that confer resistance. Although diseases controlled by monogenic loci tend to be eliminated through years of breeding from the stock, they still occur from time to time with associated losses. The specific mutations responsible for some of these diseases with a simple Mendelian mode of inheritance still eludes investigation and therefore still pose a great challenge to geneticist. On the other hand, some of the most economically important diseases of livestock are controlled by variations on many genes, further compounded by host $\times$ pathogen $\times$ environment interactions. Elucidating the genetic basis of such diseases has been most challenging and research efforts are intensifying in this regard. In this review, we shall attempt to summarize and analyze the types of reported mutations responsible for some animal (cattle, goat, pig and sheep) diseases in today's agriculture.

\section{Functional consequences of DNA polymorphisms in single-locus-disease genes}

About 200 diseases of cattle, goat, pig, and sheep are thought to be caused by sequence variations in single genes, of which the causal mutations in less than half of them have been elucidated. The causal mutations are found in the coding and noncoding regions with profound consequences on mRNA processing and stability of the protein product. Further information on animal diseases with a simple mode of inheritance can be seen at http://www.omia.angis.org.au/. Table 1 presents a summary of the genes and type of mutations implicated in several diseases of livestock.

Coding region disease variants and the consequences for causal mutations

The coding region is the portion of a gene that is transcribed and translated into proteins and does not include such regions as a recognition site, initiator sequence, or termination sequence. All the different types of polymorphisms have been reported in monogenic disease genes of livestock. The majority of cases are caused by SNPs with varying degrees of effects on gene action, such as substituting one amino acid for another, duplications and deletions that lead to frame shift and premature termination of translation, and complete deletion of entire exon(s) or gene(s) in diseased individuals. These changes in coding regions have been recognized to influence gene function by affecting mRNA splicing patterns (Cartegni et al. 2002) or by altering protein function.

In a simple amino acid exchange caused by a SNP, one may not expect much change in protein function or abundance because only one amino acid out of hundreds of others has been altered. However, the amino acid in question or the part of the protein where the change takes place determines the effect of the mutation. In most reports, pathologic mutations are found to occur in functionally conserved regions of the protein, with effects ranging from reduced expression of the mutant protein, to altered function, to complete abolition of expression. In a disease condition like complex vertebral malformation in cattle, Thomsen et al. (2006) found the causal mutation to be a substitution of thymine for guanine (nucleotide 559) of the SLC35A3 gene, which led to a change in amino acid 180 , from valine to phenylalanine. This mutation results in abnormal nucleotide-sugar transport into the Golgi apparatus, thus disrupting normal protein glycosylation. In bovine Ehlers-Danlos syndrome, Tajima et al. (1999) reported a SNP (G254A) that occurred in the serine-glycine dipeptide repeat region of the binding portion of $D S P G 3$ gene. The G254A substitution might be considered a simple nucleotide change, but it caused an amino acid change (serine to asparagine) that is responsible for functional abnormality in cutaneous tissues of carrier individuals. Another mutation, A383G or Asp128Gly, detected in a highly conserved region of the extracellular portion of the $C D 18$ gene (codes for a glycoprotein), is responsible for leukocyte adhesion deficiency (LAD) in Holstein cattle (Shuster et al. 1992). Shuster et al. (1992) estimated the carrier frequency of the Asp128Gly allele at about $15 \%$ in bulls of U.S. Holstein populations and at about $6 \%$ in cows. This mutation is also present in Holstein cattle throughout the world, making LAD one of the most common genetic diseases of Holstein cattle. Also, substitution of an evolutionarily conserved glutamic acid by lysine (p.Glu1200Lys), caused by a c.3598G $>$ A transition in the FBN1 gene, results in bovine Marfan syndrome (Singleton et al. 2005). The glutamic acid residue is part of a calcium-binding epidermal growth factor-like molecule, which is also frequently altered in human Marfan syndrome (Rantamaki et al. 1999).

In some instances, different SNPs on the same gene are known to be responsible for the same genetic disorder in different breeds. A good example is bovine lysosomal $\alpha$-mannosidosis whereby a T961C (or Phe321Leu) is 


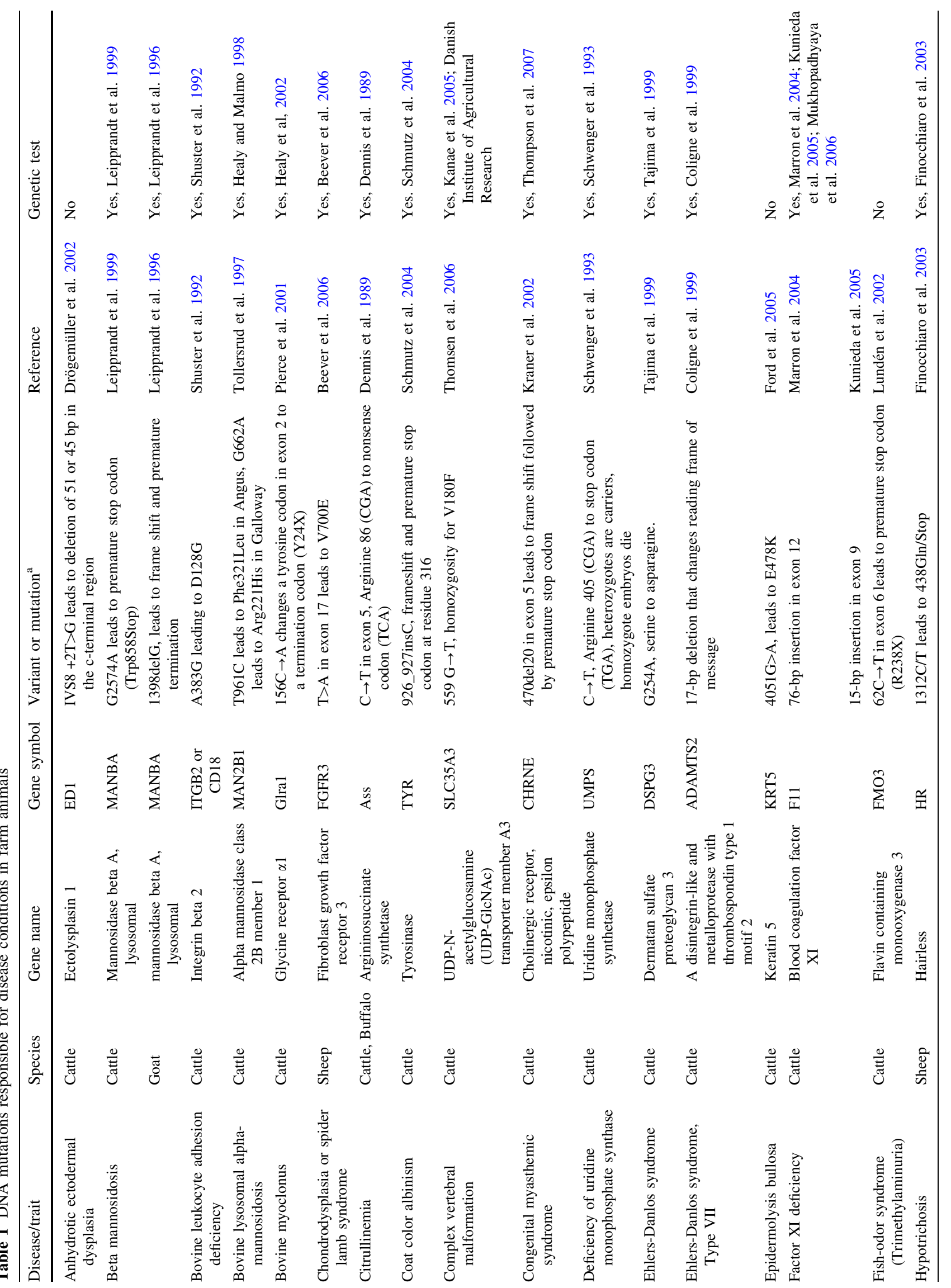




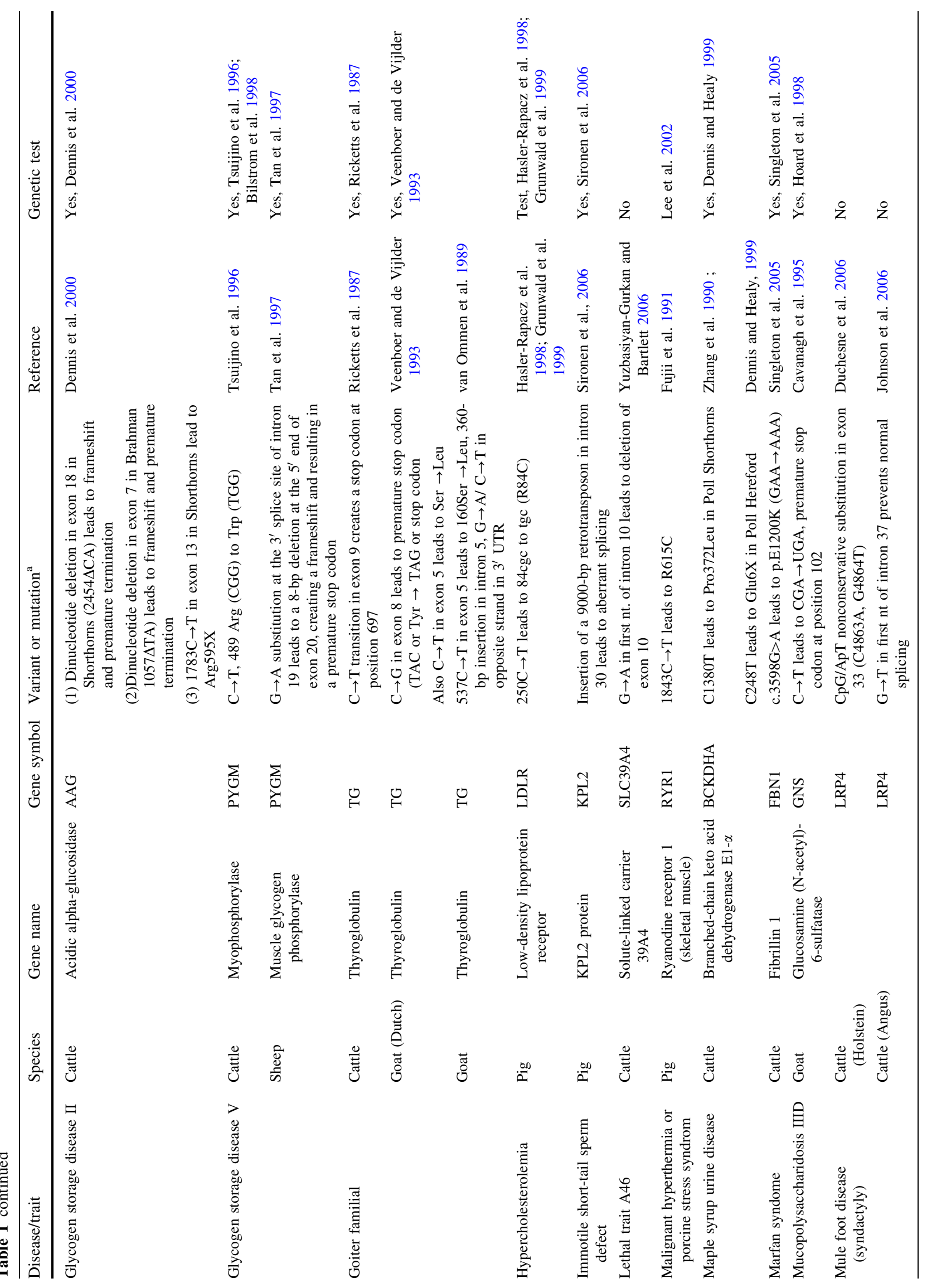




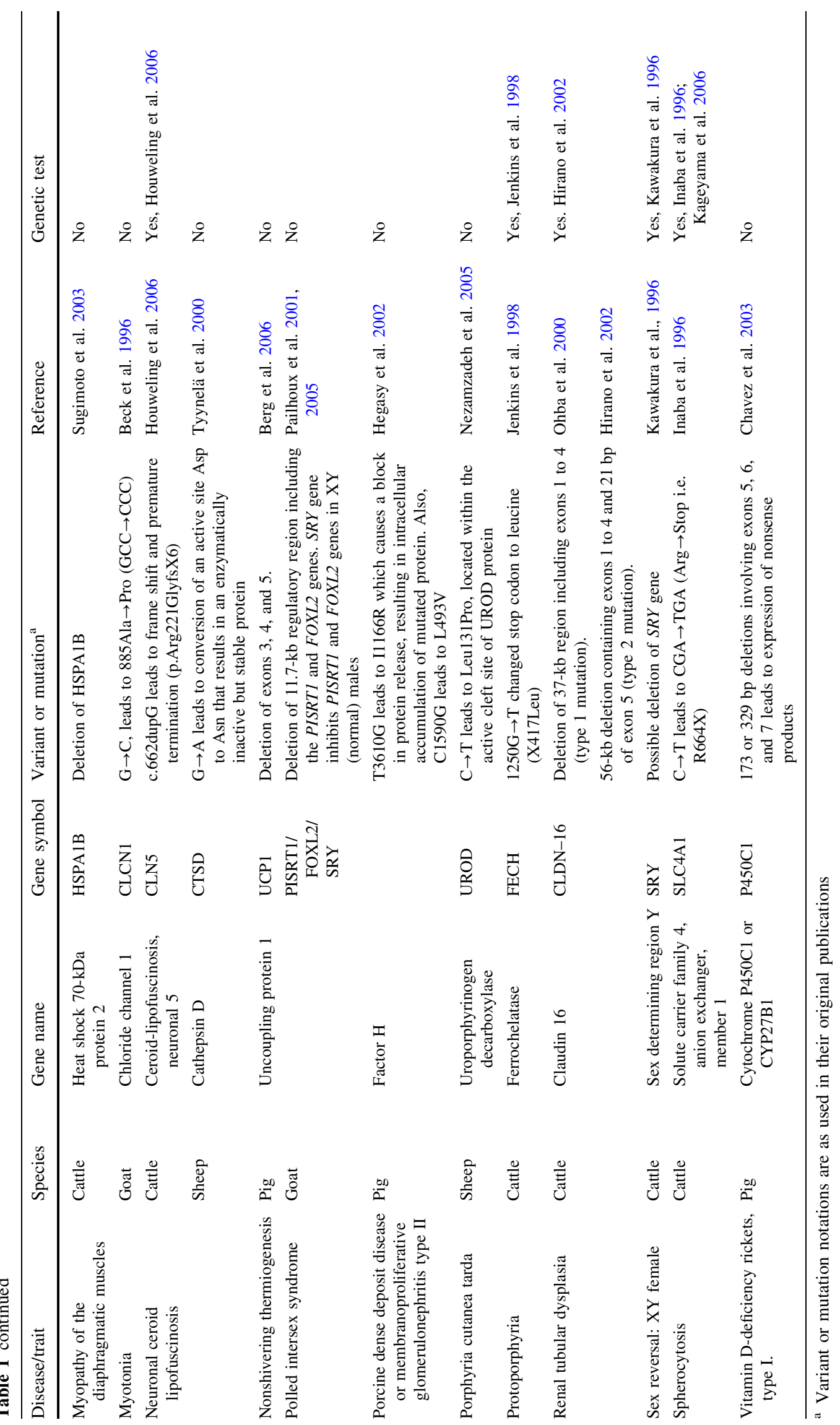


responsible for the condition in Angus cattle, while G662A (or Arg221His) is the causal polymorphism in Galloway cattle (Tollersrud et al. 1997). The amino acids substituted in both cases are conserved among the $\alpha$-mannosidase class-2 family, indicating important roles in protein function. Their independent substitution therefore disrupted the function of the protein, to the same extent, leading to a deficiency of lysosomal $\alpha$-mannosidase. Molecular heterogeneity also exists in bovine maple syrup urine disease (MSUD) (Dennis and Healy 1999; Zhang et al. 1990) and glycogen storage disease II (Dennis et al. 2000). Zhang et al. (1990) investigated Polled Shorthorn with MSUD and found the causal mutation to be $248 \mathrm{C} \rightarrow \mathrm{T}$ in exon 2 of the $B C K D H A$ gene that is responsible for converting 6 glutamine to a premature stop codon. In Polled Herefords conversely, the same condition is caused by a $1380 \mathrm{C} \rightarrow \mathrm{T}$ (Pro372Leu) mutation in the same gene (Dennis and Healy 1999). In both cases an important functional part of the gene is either absent (premature stop codon) or altered (Pro372Leu). Further investigations with crosses of Polled Herefords and Polled Shorthorns with the disease showed heterozygosity for both mutations (Healy and Dennis 1994).

SNPs that change an amino acid to a stop codon bring about premature termination and, in some of the monogenic-disease loci in livestock, lead to a complete disruption in protein synthesis or the production of shorter transcripts with decreased activity. Such conditions are usually responsible for nonsense-mediated mRNA decay (Culbertson 1999). Goiter in both cattle and goats develops from SNPs that cause premature termination of mRNA translation of the $T G$ gene (Ricketts et al. 1987; Veenboer and de Vijlder 1993). A nonsense mutation (R238X) in the FMO3 gene that underlies fishy off-flavor in cow's milk was shown to eliminate about $50 \%$ abundance of the gene in heterozygous carriers (Lundén et al. 2002). Complete lack of FMO3 activity, necessary for complete oxidation of trimethylamine to an odorless compound, may therefore be the case in homozygous carriers of the condition. Pierce et al. (2001) observed that the molecular basis of bovine myoclonus is the substitution of tyrosine by a termination codon (Tyr24X) in exon 2 of the Glral gene. The stop codon results in a prematurely truncated protein that lacks ligand-binding and membrane-spanning domains. In bovine beta mannosidosis, the lack of $22 \mathrm{C}$-terminal amino acids in mutant proteins, the result of a nonsense mutation in the MANBA gene, indicates their importance in the stability and proper functioning of the enzyme (Leipprandt et al. 1999). In the same condition in goats, an earlier termination of mRNA synthesis is brought about by a single base deletion (1398delG) that results in a shift in the reading frame and production of a shorter peptide, 481 amino acids compared with 879 amino acids of the normal protein (Leipprandt et al. 1996). Deficiency of uridine monophosphate synthase in cattle also results from a mutant protein lacking $76 \mathrm{C}$-terminal amino acids (Schwenger et al. 1993). A rare situation occurs in bovine protoporphyria where a SNP changes a stop codon to a coding amino acid (TGA to TTA or X417Leu) thereby adding 27 more amino acids to mutant proteins (Jenkins et al. 1998). This addition affects catalytic activity of the enzyme since it occurs in the carboxyl terminal, known to play important roles in catalytic function.

Single-base-pair (bp) deletions or insertions to exons and whole genes are also important players in altering protein function and causing disease conditions in farm animals. In addition to the single-bp deletion that caused caprine mannosidase beta described above, a 17-bp deletion in ADAMTS2 is responsible for Ehlers-Danlos syndrome type VII in cattle (Colige et al. 1999), while a 20-bp deletion in CHRNE causes bovine congenital myasthemic syndrome (Kraner et al. 2002). Larger deletions involving whole exons are reported for genes causing bovine renal tubular dysplasia (Hirano et al. 2002; Ohba et al. 2000) and porcine nonshivering thermiogenesis (Berg et al. 2006). On a more dramatic note, whole genes are deleted or suspected of being deleted in conditions like bovine myopathy of the diaphragmatic muscles (Sugimoto et al. 2003), sex reversal (XY female) in cattle (Kawakura et al. 1996), and polled intersex syndrome in goats (Pailhoux et al. 2005). Reports of pathologic insertions range from single bp to several hundred bp in conditions like bovine factor XI deficiency and bovine neuronal ceroid lipofuscinosis (Houweling et al. 2006; Kunieda et al. 2005; Marron et al. 2004). The effects of these deletion/insertion mutations include shift in reading frame and premature termination and, in extreme cases like whole gene deletions, total absence of protein activity.

\section{Consequences of causal SNPs in noncoding regions}

The noncoding regions of genes constitute the promoter, $5^{\prime}$ and $3^{\prime}$ untranslated regions (UTRs), introns, and intergenic or large regions between genes. In these regions are found regulatory sequences that affect gene splicing, transcription, and translation. Polymorphisms in these regions can alter gene expression as has been demonstrated as the genetic basis of some animal diseases with a simple mode of inheritance.

Deletion of a 11.7-kb intergenic region on the $\mathrm{Y}$ chromosome triggers intersexuality and polledness in goats (Pailhoux et al. 2001). This region contains mainly repetitive sequences and its deletion affects the transcription of two genes, namely, PISRT1 that encodes a $1.5-\mathrm{kb}$ mRNA devoid of open reading frame, and FOXL2, known to be responsible for blepharophimosis epicanthus inversus 
syndrome in humans (Crisponi et al. 2001). The deletion, even though located 20 (PISRT1) and 200 (FOXL2) kb away from the genes, contains regulatory sequences whose absence has direct consequences on the transcription of both genes. In goats with $\mathrm{XX}$ sex-reversed gonads, the expression of PISRT1 decreases between 36 days postcoitus (dpc) and $40 \mathrm{dpc}$ accompanied with an increase in SOX9 expression (Pailhoux et al. 2001). SOX9 gene is an important regulator of testis development that functions by triggering $A M H$ transcription (Arango et al. 1999; Koopman 1999). On the other hand, FOXL2 is involved in early ovarian differentiation and development, possibly by having a function in folliculogenesis (Crisponi et al. 2001; Pailhoux et al. 2001). In normal circumstances, therefore, PISRT1 functions by inhibiting SOX9 as an antitestis gene while FOXL2 promotes ovarian development. In normal males, another gene, $S R Y$, has the inhibitory function of inactivating the transcription of both genes.

Intronic splice-site mutations are responsible for ovine glycogen storage disease, mule foot, lethal trait A46, and anhydrotic ectodermal dysplasia diseases of cattle (Drögenmüller et al. 2002; Johnson et al. 2006; Tan et al. 1997; Yuzbasiyan-Gurkan and Bartlett 2006). In ovine glycogen storage disease, a $\mathrm{G} \rightarrow \mathrm{A}$ transition at the $3^{\prime}$ splice site of intron 19 of the PYGM gene causes a frame shift in translation, resulting in a premature codon and the removal of the last 31 amino acid residues from the C-terminal of the protein in affected individuals (Tan et al. 1997). Consequently, there is a deficiency of the muscle glycogen phosphorylase enzyme which is responsible for catalyzing breakdown of muscle glycogen stores to glucose-1-phosphate in affected individuals (Schmid and Mahler 1959). Another $\mathrm{G} \rightarrow \mathrm{A}$ transition at the first nucleotide of intron 37 of the LRP4 gene completely disables this donor splice site, thereby abrogating the normal splicing of the gene (Johnson et al. 2006). The effect of the mutation of this highly conserved guanine base is the disruption of the normal functioning of the protein in affected individuals through the production of a dysfunctional membrane-anchored receptor lacking the normal cytoplasmic domain (Johnson et al. 2006). There is reduced mobility accompanied by painful fusion of hooves in affected subjects. A further splice-site variant, also a $\mathrm{G} \rightarrow \mathrm{A}$ transition of the first nucleotide of intron 10 (SCL39A4 gene) leads to the outsplicing of the entire exon 10 in affected animals (Yuzbasiyan-Gurkan and Bartlett 2006). The resultant protein is predicted to lack two critical motifs implicated in the formation of a pore responsible for impaired zinc absorption in diseased individuals (Yuzbasiyan-Gurkan and Bartlett 2006). Another splice-site donor variant involves a $\mathrm{G} \rightarrow \mathrm{T}$ transversion located at the second position of intron 8 of the $E D 1$ gene resulting in anhydrotic ectodermal dysplasia phenotype in cattle (Drögenmüller et al. 2002). The effect of this mutation is a translated protein with a large deletion in the functionally important C-terminal tumor necrosis factor-like domain. Recent findings suggest that the EDI gene plays a role in the development of mucous glands, the absence of which resembles a feature of X-linked anhydrotic ectodermal dysplasia in human patients (Seeliger et al. 2005).

A rare situation in causal SNPs in noncoding regions is the insertion of a 9000-bp retrotransposon within intron 30 of the KPL2 gene which causes immotile short-tail sperm defect in pig (Sironen et al. 2006). Interestingly, the inserted retrotransposon affects splicing of the KPL2 transcript in two ways: it causes either skipping of an upstream exon or inclusion of an intronic sequence as well as part of the insertion in the transcript. Both scenarios alter the reading frame leading to premature termination of translation. Sironen et al. (2006) further demonstrated that the aberrantly spliced exon is expressed predominantly in testicular tissue, thus explaining the tissue specificity of the immotile sperm defect and the importance of the KPL2 gene in correct axoneme development.

\section{Functional consequences of DNA variations in multigenic-disease loci}

Several economically important diseases of farm animals, including mastitis, transmissible spongiform encephalopathies (TSEs), brucellosis, dermatophilosis, trypanosomiasis, and tick resistance, pose a problem for satisfactory control or complete eradication because of the complex interplay of factors that support their development, namely, the pathogen, the environment, and animal-related factors. Initial methods of control like changes in management, treatment, vaccination, pathogen control, movement control, slaughter, isolation, and quarantine of diseased animals are no longer attractive due to increased pathogen resistance to chemotherapeutic and prophylactic drugs and antibiotic residues in the environment and animal products, just to mention a few. The option of exploiting host genetic resistance to control these diseases does not suffer these drawbacks in the broad sense and is the key to cheap and effective control. Unfortunately, these diseases are under the interplay of many gene loci that must be identified and characterized before satisfactory control can be achieved. The search for diseaseresistance markers involves screening for association between disease resistance and a variety of polymorphisms in candidate genes and anonymous markers and mapping for quantitative trait loci (QTLs). In particular, genetic traits of innate and acquired immunity related to resistance have received considerable attention and there is now evidence linking variations within some of these genes with resistance to diseases. 
In particular, genes of the major histocompatibility complex (MHC) or BoLA system (http://www.ebi.ac.uk/ $\mathrm{ipd} / \mathrm{mhc} /$ ) are thought to play a role in host resistance against the development of these diseases. In cattle, the BoLA system is located on chromosome 23 and includes three classes of loci: class I (locus A); class II, divided into IIa (includes loci DRA, DRB1-3, DQA, DQB, etc.) and IIb (includes DOB, DYA, DYB, DIB, etc.); and class III (includes TNF, 21-OH, C4, BF, HSP70-1 and -2, EAM, PRL, etc.) (Rothschild et al. 2000; http://www.ebi.ac.uk/ipd/mhc/). The first two groups of loci code for surface molecules relevant in the induction and regulation of immune responses. Some of these genes are highly polymorphic, with about 100 different alleles described for DRB3 exon 2 and about 39 for DQB (Maillard et al. 2001; da Mota et al. 2004; http://www. projects.roslin.ac.uk/bola/). Numerous lines of evidence indicate that the extensive polymorphisms reported for these molecules are responsible for the differences among individuals in immune responses to infectious agents. Some of the advances achieved so far for a few of these diseases and their associated resistant/susceptible polymorphisms will now be examined individually.

\section{Mastitis}

Mastitis is one of the most frequent, complex, and costly diseases of dairy cattle, goat, and sheep and its development is influenced by many genes, the environment, and pathogen factors. Host genes that are receiving attention are immunity traits and mainly include antibody response and functionality of neutrophils whose presence and functionality are essential in the innate defense against udder infections. The genetic variability of the immune mechanisms underlying mastitis resistance, including such genes as $C D 14, C D 18$, lactofferin, lysozyme, and class I and class II genes of MHC, have been reviewed by Detilleux (2002), Paape et al. (2003), and Rupp and Boichard (2003) and could therefore aid in selection for mastitis resistance.

In dairy cattle, most studies have focused on exon 2 of the class II BoLA DRB3 because of its high polymorphism. In an early study, Dietz et al. (1997) associated DRB3.2*16 with an increased risk for acute intramammary infection (mastitis). In the same year, Kelm et al. (1997) associated the same allele with higher estimated breeding value (EBV) for somatic cell score, and also DRB3.2*8, $\operatorname{IgG2^{b}}$, and $C D 18^{A l}$ with increased $\mathrm{EBV}$ for clinical mastitis. On the contrary, Sharif et al. (1998) significantly associated DRB3.2*16 with lower somatic score or lower risk of mastitis in Holsteins but reported significant association of DRB2.3*23 with occurrence of severe mastitis. The presence of glutamic acid at position $\beta 74$, a motif present in DRB3.2*22, *23, and $* 24$ alleles, was recently associated with occurrence of mastitis caused by
Staphylococcus spp. (Sharif et al. 2000). Similarly, the same authors indicated that the presence of arginine or lysine at position 13 of a motif present on DRB $3.2 * 23$ and *8 alleles showed a tendency toward association with a higher risk of clinical mastitis; likewise, with presence of arginine at position $\beta 71$ (present in alleles $* 23$ and $* 22$ ). More recently, Rupp et al. (2007) associated DRB3.2*3 and $* 11$ with lower somatic cell counts (SCC), alleles $* 22$ and $* 23$ with higher SCC, allele $* 3$ with less clinical mastitis, and $* 8$ with a higher mastitis risk. For MHC Class I molecules, several studies have reported a relationship between different alleles with mastitis resistance or susceptibility (Mallard et al. 1995; Mejdell et al. 1994). Conflicting as some of these results may seem, most still point to the fact that variations within the BoLA system genes predispose to mastitis.

On immune genes, CXCR2, a chemokine receptor required for neutrophil migration to infection sites, contains a SNP $(+777 \mathrm{G} \rightarrow$ C) (Grosse et al. 1999; GenBank No. U19947) that is located in a region involved in mediating calcium signaling and mobilization as well as Gprotein binding. Youngerman et al. (2004) showed that the +777GG genotype was associated with decreased percentages of subclinical mastitis, while genotype CC had increased percentages of subclinical mastitis in Holstein cows. No difference in clinical mastitis incidence was observed between genotypes. In the same light, cows with +777CC or CG genotype showed significantly lower neutrophil migration to recombinant human (rh) IL-8 than those of GG genotype (Rambeaud and Pighetti 2005). Furthermore, they also demonstrated that neutrophil migration of +777CC genotype to zymosan-activated serum was slower compared to the other genotypes, and upregulation of CD18 expression after stimulation with rhIL-8 was also decreased. Further to the search, Rambeaud et al. (2006) reported a significant increase in survival of neutrophils from cows with genotype $+777 \mathrm{CC}$ in response to IL-8 compared with genotype $+777 \mathrm{GG}$. On the other hand, they observed a significant reduction in neutrophil reactive oxygen species (ROS) generation in response to phorbol-13-myristate-12 acetate by neutrophils of $+777 \mathrm{CC}$ than of $+777 \mathrm{GG}$, although no differences in bactericidal activity or glutathione levels were observed among genotypes. These results indicate that neutrophils from cows with different $C X C R 2$ genotypes vary in their ability to suppress apoptosis and produce ROS and therefore may partly explain the inter- and intraindividual variations observed in the development of mastitis. In $C C R 2$, another chemokine receptor gene, Leyva-Baca et al. (2007) associated c.414C $>\mathrm{T}$ with estimated breeding value for somatic cell score and udder depth in Canadian Holsteins, which indicates possible relationships with mastitisrelated traits and estimated breeding values. 
Other attempts at finding markers responsible for mastitis incidence/resistance include anonymous markers in genome scan approaches (Van Tassel et al. 2000) and mapping of QTLs with effects on SCC and clinical mastitis on the 29 autosomes of cattle (Khatar et al. 2004; Sugimoto et al. 2006). The mapping of a QTL to a particular location of the genome points to the location where the actual gene(s)/mutations responsible for the effect in question may be located. As a result, genes in the vicinity of a QTL are targets for possible associations with the condition in question. For example, Sugimoto et al. (2006) sequenced three genes in the vicinity of a QTL for SCC and reported a three-base insertion in the glycine-coding stretch of FEZL gene (a transcription factor with a role in neuronal development) that resulted in the extension of 12 glycine (12G) residues to 13 (13G). Further analysis indicated that $12 \mathrm{G}$ FEZL influences resistance to mastitis. Their results also indicated that FEZL induced lower expression of SEMA5A (axon-attracting molecule semaphorin 5A) in susceptible animals (13G). Meanwhile, in resistant animals (12G), enhanced SEMA5A induced expression of at least nine genes related to immune responses, including $T N F-\alpha$ and $I L-8$. The implication of their findings is that susceptibility to mastitis results from an impaired immune response due to the lower transcription activity of FEZL.

Transmissible spongiform encephalopathies or prion diseases

Transmissible spongiform encephalopathies (TSEs), also known as prion diseases, are caused by the conversion of the host-encoded prion protein $(\mathrm{PrP})$ or normal cellular prion protein $\left(\mathrm{PrP}^{\mathrm{c}}\right)$ into a misfolded abnormal form of the protein. The misfolded prion protein $\left(\mathrm{PrP}^{\mathrm{sc}}\right)$ results from point mutations at the PRNP locus. There is, however, recent evidence implicating other genes or agents involved in the etiology of TSE (Diaz et al. 2005; Lloyd et al. 2001; MarcosCarcavilla et al. 2007) thus making it a polygenic trait whose resistance/susceptibility is controlled by one major gene $(P R N P)$ and modulated by several other genes. For this reason, we have decided to discuss TSE in this section.

TSEs may occur as genetic, infectious, or sporadic disorders in humans, cattle, sheep, goat, deer, and other domestic animals (reviews by Priola and Vorberg 2004; Doherr 2006). The most common forms of TSEs are scrapie in sheep and goats and bovine spongiform encephalopathy (BSE) in cattle. One human form of TSE, variant Creutzfeldt-Jacob disease, is thought to be caused by BSE through the consumption of beef (Scott et al. 1999), making TSE elimination from the food chain a priority by most governments.

In sheep, about 23 SNPs in the PRNP gene have been reported, of which three SNPs causing amino acid changes within the protein-coding sequence have been associated with scrapie development (incubation period, pathology, and clinical signs) (reviewed by Baylis and Goldmann 2004). The most important SNPs in terms of scrapie susceptibility/resistance are SNPs that lead to amino acid changes at codons $136(\mathrm{~A} \rightarrow \mathrm{V}), 154(\mathrm{R} \rightarrow \mathrm{H})$, and 171 $(\mathrm{Q} \rightarrow \mathrm{H}$ or $\mathrm{Q} \rightarrow \mathrm{R})$ (Belt et al. 1995; Goldmann et al. 1990). $136 \mathrm{~V}$ has been associated with scrapie susceptibility in both natural and experimental conditions, while 171R is associated with low incidence (Belt et al. 1995; Hunter et al. 1993; Maciulis et al. 1992). These common variants, however, define five PRNP haplotypes, namely, ARQ $\left(\mathrm{A}_{136} \mathrm{R}_{154} \mathrm{Q}_{171}\right), \mathrm{ARR}, \mathrm{ARH}, \mathrm{AHQ}$, and VRQ, that result in 15 genotype combinations, each with an associated degree of risk (Table 2). For instance, animals homozygous for VRQ rapidly develop clinical signs of scrapie when infected and are considered highly susceptible, while animals homozygous for ARR are resistant (Belt et al. 1995; Hunter et al. 1996). Susceptibility of the haplotypes ARQ, AHQ, ARH, and ARK is more complex and varies with breed. For example, ARQ/ARQ is the common genotype for scrapie cases in Suffolk sheep (Hunter et al. 1997a, b), while scrapie is rare in Texel sheep of this genotype (Dawson et al. 1998). Furthermore, 171R is dominant for increased scrapie resistance, implying that flocks derived from 171RR founder animals are expected to remain scrapie-free, even under exposure. In a recent study, Green et al. (2006) reported 36 previously unreported polymorphisms in the $P R N P$ gene and further defined regions of strong linkage disequilibrium with the common resistant/susceptible haplotypes. In their study, the amino acid residues A136, R154, and Q171 were found within nine larger haplotypes spanning the entire PRNP gene (promoter, $5^{\prime} \mathrm{UTR}$, coding region, and $3^{\prime}$ UTR). Also, VRQ was observed on two of these larger haplotypes and ARR, ARH, and AHQ on one each. The significance of these observations to scrapie susceptibility, which may explain the variation observed with some genotypes, remains to be elucidated.

QTLs involved in resistance/susceptibility to scrapie and other TSEs in a region close to $I L I B$ and $I L I R N$ genes on sheep chromosome 3 and mouse chromosome 2 (Lloyd et al. 2001; Manolakou et al. 2001; Moreno et al. 2003a, b) and in cattle (Zhang et al. 2004) have been reported. Marcos-Carcavilla et al. (2007) recently characterized the $I L I B$ and ILIRN genes in sheep and also reported, respectively, 29 SNPs and 1 insertion and 2 SNPs and a 14bp deletion within the genes. Expression analysis of the two genes by real-time RT-PCR found a significant increase in mRNA concentration of the genes in the cerebellum of scrapie-infected sheep but not in healthy sheep. Their findings are in agreement with previous studies (Campbell et al. 1994; Cunningham et al. 2005) that revealed an altered proinflamatory cytokines profile 
Table 2 A summary of prion protein gene $(P R N P)$ genotypes associated with different scrapie phenotypes in sheep and goat

\begin{tabular}{|c|c|c|c|}
\hline $\begin{array}{l}\text { Species/ } \\
\text { breed }\end{array}$ & $P R N P$ genotype & Scrapie phenotype & Reference \\
\hline \multirow[t]{7}{*}{ Sheep } & $\mathrm{ARR}^{\mathrm{a}}$ & Resistant genotype & Belt et al. 1995 \\
\hline & VRQ & Susceptible genotype & Belt et al. 1995 \\
\hline & ARH & May be neutral & Dawson et al. 1998 \\
\hline & AHQ & $\begin{array}{l}\text { Associated with resistance in } \\
\text { some breeds but not in others }\end{array}$ & Dawson et al. 1998 \\
\hline & VRQ/VRQ & $\begin{array}{l}\text { Carriers develop rapid clinical } \\
\text { signs of scrapie when infected }\end{array}$ & $\begin{array}{l}\text { Belt et al. 1995; Hunter } \\
\text { et al. 1996; Baylis } \\
\text { et al. } 2002\end{array}$ \\
\hline & ARQ/ARQ & $\begin{array}{l}\text { Scrapie susceptible in some } \\
\text { breeds and not in others }\end{array}$ & $\begin{array}{l}\text { Hunter et al. } 1997 \mathrm{a}, \mathrm{b} \\
\text { Dawson et al. } 1998\end{array}$ \\
\hline & ARR/ARR & Carriers are highly resistant & $\begin{array}{l}\text { Belt et al. 1995; Hunter } \\
\text { et al. 1996; Baylis } \\
\text { et al. } 2002\end{array}$ \\
\hline \multirow[t]{5}{*}{ Goat } & $\begin{array}{l}\mathrm{VV}_{21}, \mathrm{LL}_{23}, \mathrm{GG}_{49}, \mathrm{SS}_{49}, \mathrm{HH}_{143} \\
\mathrm{HR}_{143}, \mathrm{RR}_{154}, \mathrm{PP}_{168}, \mathrm{PP}_{240} \\
\mathrm{SP}_{240} \text { and } \mathrm{SS}_{240}\end{array}$ & $\begin{array}{l}\text { Variants found in scrapie } \\
\text { affected goats }\end{array}$ & Billinis et al. 2002 \\
\hline & $\mathrm{R}_{143}$ and $\mathrm{H}_{154}$ & $\begin{array}{l}\text { Moderately protective against } \\
\text { scrapie }\end{array}$ & Billinis et al. 2002 \\
\hline & K222 & $\begin{array}{l}\text { Associated to healthy animals or } \\
\text { scrapie resistance }\end{array}$ & $\begin{array}{l}\text { Acutis et al. 2006; } \\
\text { Vaccari et al. } 2006\end{array}$ \\
\hline & Q168 & $\begin{array}{l}\text { Associated with scrapie } \\
\text { susceptibility }\end{array}$ & Acutis et al. 2006 \\
\hline & M142 & $\begin{array}{l}\text { Associated with prolonged } \\
\text { incubation period of scrapie } \\
\text { and BSE in goats }\end{array}$ & Goldmann et al. 1996 \\
\hline
\end{tabular}

${ }^{a}$ ARQ are amino acids at codons 136,154 , and 171 , respectively
PrP have been reported (Acutis et al. 2006; Agrimi et al. 2003; Billinis et al. 2002; Goldmann et al. 1996). Results following experimental challenge and natural infection indicate that variations at some of these codons may be relevant for scrapie susceptibility (Billinis et al. 2002; Goldmann et al. 1996, 1998). Variants associated with scrapie-affected goats include $\mathrm{VV}_{21}, \mathrm{LL}_{23}, \mathrm{GG}_{49}, \mathrm{SS}_{49}$, $\mathrm{IM}_{142}, \mathrm{HH}_{143}, \mathrm{HR}_{143}, \mathrm{RR}_{154}, \mathrm{PP}_{168}, \mathrm{PP}_{240}, \mathrm{SP}_{240}$, and $\mathrm{SS}_{240}$ (Billinis et al. 2002; Goldmann et al. 1996). In addition, all scrapie-affected animals in Billinis et al. (2002) carried $\mathrm{HH}_{143} \mathrm{RR}_{154}$. Furthermore, they associated seven $\operatorname{PrP}$ haplotypes with scrapie-affected goats and five with healthy goats, while two genotypes were common to both groups. In another study, Agrimi et al. (2003) found associations between scrapie susceptibility and the distribution of genotypes at codons 37, 143, and 240 in the Italian Ionica breed of goats.

SNPs resulting in amino acid substitutions in the bovine PRNP gene have not been found. However, silent mutations and a variable number of octapeptide repeats in the coding region as well as three mutations in the untranslated exon 1 and its $5^{\prime}$ flanking region have been reported (Goldmann et al. 1991; Humeny et al. 2002). Furthermore, no or few associations between PRNP polymorphisms and BSE incidence have been found (Neibergs et al. 1994; Sander et al. 2004). A polymorphism (T174M) in another 
gene close to $P R N P$ in humans, the flanking prion doppel gene $(P R N D)$, is involved in susceptibility to sporadic Creutzfeldt-Jacob disease (Croes et al. 2004; Jeong et al. 2005). This gene was identified in a search for genes paralogous to $P R N P$ in mouse and a linked expression between the two genes has been demonstrated (Moore et al. 1999). In contrast to the PRNP gene, SNPs in the bovine $P R N D$ gene have been observed to result in amino acid substitutions (R50H, N110H, R132Q) (Comincini et al. 2001; Luhrs et al. 2003). In addition, two synonymous SNPs, C4819T and T5063A, have been reported in German cattle breeds (Balbus et al. 2005). Haplotype and genotype analyses of BSE and control animals revealed significantly different distribution of C4815T and R13Q polymorphisms in German Simmental, while no BSE susceptibility was associated with R50H and A5063T (Balbus et al. 2005). Two synonymous SNPs are also known to occur in the ovine PRND gene.

\section{Brucellosis}

Natural resistance to brucellosis has been reported in several species, including cattle and humans (Montaraz and Winter 1986; Templeton et al. 1990). Through breeding studies with cattle, Templeton et al. (1990) reported that natural resistance to Brucella could be dramatically increased by selective breeding. With initial evidence linking the Nrampl gene to resistance/susceptibility in mice (Vidal et al. 1993), a later survey of the genes of several bovid species and the mode of inheritance of brucellosis in cattle suggest that other genes are involved in the development of this disease (Adams and Templeton 1998). In addition to several host factors that are associated with innate immunity against Brucella abortus (reviews by Baldwin and Parent 2002; Wyckoff 2002), polymorphisms within the Nrampl gene in cattle are associated with natural resistance to brucellosis (Adams and Templeton 1998; Barthel et al. 2001). Basically, these polymorphisms involve a $(\mathrm{GT})_{\mathrm{n}}$ repeat microsatellite in the $3^{\prime} \mathrm{UTR}$ of Nramp1. Adams and Templeton (1998) associated the $\mathrm{GT}_{13}$ allele with resistance toward B. abortus and the other alleles, $\mathrm{GT}_{14-16}$, with susceptibility. In another study, Paixão et al. (2006) detected $\mathrm{GT}_{13}$ in cattle genotypically resistant to brucellosis and detected $\mathrm{GT}_{14}, \mathrm{GT}_{13} / \mathrm{GT}_{14}$, or $\mathrm{GT}_{13} / \mathrm{GT}_{15}$ in genotypically susceptible cattle. However, a number of studies have found a lack of association of $\mathrm{GT}_{13}$ with resistance to bovine brucellosis (Kumar et al. 2005; Paixão et al. 2007). In humans, Bravo et al. (2006) found no association of susceptibility to brucellosis with several polymorphisms of the Nrampl gene, while significant associations have been reported in Koreans (Ryu et al. 2000). A Nrampl SNP that actually led to a change in an amino acid in mice (G169D, Vidal et al. 1993) has not been detected in any other mammalian species, including cattle. However, monocytes from naturally resistant cattle can more efficiently resist the intracellular growth of $B$. abortus than those from susceptible cattle (Qureshi et al. 1996; Templeton et al. 1990). From these accounts, it is clear that host ability to control the development of brucellosis is under the control of more than one gene, many not yet identified and characterized.

\section{Trypanosomiasis}

In many parts of Africa, Asia, and South America, trypanosomiasis is one of the main debilitating and limiting factors to animal productivity, infecting about 50 million cattle and costing producers and consumers about US $\$ 1-1.2$ billion in losses (Kristjanson et al. 1999). Present control measures include limitation of the tsetse vector through the widespread use of insecticides and the use of trypanocidal drugs to treat sick animals. The use of insecticide comes with extra cost and associated environmental problems, while trypanocidal drugs are limited and resistance to them is growing steadily. However, some local breeds of cattle (N'Dama, Muturu, Namchi), sheep (West African Dwarf), and goats (West African Dwarf) in the central/west African region show natural resistance to the disease (Agyemang 2005). The ability to naturally resist trypanosome infections, also known as trypanotolerance, results from several biological mechanisms under multigenic control (review by Naessens 2006). Understanding of the genes that control the trypanotolerant trait may offer new, cheaper, and safer approaches to improving productivity of animals in endemic zones.

To date, numerous studies have been conducted but the key genes responsible for susceptibility/resistance have not been identified and characterized. The results of several studies have shown that trypanotolerant livestock have a remarkable capacity to control parasitemia and, thus, the development of severe anemia during infection (Dolan 1987; Gibson 2001; Trail et al. 1991, 1992). In an analysis of Boran/N'Dama chimeric twins, Naessens et al. (2003) confirmed that trypanotolerance is mediated by two independent mechanisms, (1) a better capacity to control parasitemia, which was suggested not to be due to differences in immune responses, and (2) a better capacity to control associated anemia, mediated by cells from the hemopoietic system. Therefore, two pools of genes are involved but none of the numerous studies, including zootechnical surveys (d'Ieteren et al. 1998; Murray et al. 1991), quantitative genetic studies (Trail et al. 1994), electrophoretic analysis of targeted proteins (Queval and Bambara 1984; Queval and Petit 1982), and genotyping of genes of the MHC (Maillard et al. 1989), have been able to identify trypanotolerance genes. Using the QTL approach, 
Hanotte et al. (2003) analyzed 16 bovine phenotypes, including anemia, body weight, and parasitemia, and identified 18 QTLs linked to trypanotolerance. Their study further indicated that trypanotolerance is a highly polygenic trait with each gene or locus explaining only about $10-12 \%$ of the phenotypic variance of the trait. Most of the identified QTLs were linked to the control of anemia, suggesting that anemia control is complex and of major significance, and only a few were linked to parasitemia. Some authors have recently used the serial analysis of gene expression (SAGE) approach and have identified 187 genes that changed their expression in N'Dama leukocytes after infection by $T$. congolense (Berthier et al. 2003; Maillard et al. 2004, 2005). In another study using SAGE, Berthier et al. (2006) have constructed four different mRNA transcript libraries from the white blood cells of a N'Dama trypanotolerant animal obtained at different stages of development of experimentally induced trypanosomiasis (by $T$. congolense). The libraries contain about 75,000 sequences, including several known genes, described or expressed sequence tags, and completely new genes that may be functional in trypanotolerance. The availability of these libraries may now facilitate the identification of genes and the functional mutations responsible for trypanotolerance in cattle and therefore better options for control. In humans, on the other hand, Courtin et al. (2006) have associated two SNPs (IL10 $1592 \mathrm{C} / \mathrm{A}$ and $\mathrm{TNF}_{-308 \mathrm{G} / \mathrm{A}}$ ) with the development of African trypanosomiasis whereby the IL10_592 A allele was found to present a lower risk of disease while $\mathrm{TNF}_{-308}$ a presented a higher risk of developing the disease early after exposure.

\section{Dermatophilosis and other tick infections}

Dermatophilosis, a severe skin disease of ruminants, is caused by the filamentous actinomycete bacterium Dermatophilus congolensis and is aggravated by the presence of the tick Amblyomma variegatum (Ambrose et al. 1999; Morrow and Compton 1991). It results in the death of up to $15 \%$ of infected stock. Present control measures are hampered by the development of chemoresistance to acaricides and antibiotics and there is little success in the development of a vaccine against the disease. However, field studies indicate differential breed response to the development of severe dermatophilosis, particularly a higher resistance by the west African N'Dama (taurine) breed, intermediate resistance by zebu breeds like the Sanga of Ghana and Gudali of Cameroon, and high susceptibility by imported (into tropical regions) breeds like Friesian (Koney et al. 1994; Leroy and Marchot 1987; Mattioli et al. 1995). Several studies on host immunity to dermatophilosis suggest two possible mechanisms of immunity: antibodymediated prevention of the establishment of infection and antibody- or cell-mediated clearance of infection (How and Lloyd 1988; Martinez et al. 1993). Consequently, immune genes of the MHC in cattle have been studied for their role in the development of dermatophilosis. In a study on Brahman zebu cattle in Guadeloupe, classified according to absence or presence of clinical signs into, respectively, dermatophilosis resistant or susceptible, Maillard et al. (1996) reported an amino acid sequence in exon 2 of BoLA $D R B 3$ gene associated with a BoLA class I specificity as a possible genetic marker of resistance to dermatophilosis. The sequence EIAY, located at amino acid positions 66, 67,74 , and 78 within the antigen recognition sites (ARS), was found in 12 animals classified as resistant, and 10 of them also displayed class I BoLA-A8 specificity. Furthermore, only 3 of 18 susceptible animals showed simultaneously the DRB3 EIAY sequence and BoLA-A8 specificity. Also, they found a serine residue at position 30 of the ARS of eight susceptible animals which was completely absent in all resistant animals. Their results thus associate MHC haplotypes, BoLA-A8 specificity and the BoLA-DRB3 EIAY, and lack of serine at position 30 with resistance to dermatophilosis. Other BoLA-DRB3 and BoLA-DQB alleles in relation to dermatophilosis have been characterized in cattle (Maillard et al. 1999, 2001; http://www.ri.bbsrc.ac.uk/bola/). One of the most significant markers strongly associated with dermatophilosis susceptibility (96\%) involves two linked alleles of exon 2 DRB*09 (amino acid sequence C-E-S-F-L-QK-N in APS positions 11-28-30-37-67-70/71-74, respectively) and DQB*1804 genes (Maillard et al. 2002). Elimination of animals possessing this haplotype by marker-assisted selection reduced the incidence of dermatophilosis from $76 \%$ to $2 \%$ over a period of 5 years (Maillard et al. 2002). A recent study also found a MHC allele associated with hypersensitivity to dermatophilosis in previous studies of the Renitelo cattle of Madagascar (Razafindraibe et al. 2006). The $\mathrm{DRB} * 09$ marker sequence may be exposed to proteases possibly hindering recognition by a $\mathrm{T}$ cell receptor (Maillard et al. 2003). In the Maillard et al. (2002) study, only about $30 \%$ of susceptible animals possessed the DRB*09/DQB*1804 marker, indicating the possibility of the involvement of other markers or minor players.

Like dermatophilosis, host ability to develop tick resistance has been recorded in ruminants and has also been a subject for study for many years. Tick infestations of several species, e.g., Boophilus microplus, B. decolorants, Amblyomma americanum, A. bebraeum, A. variegatum, have received differential host responses by different cattle breeds located in different regions. For example, the N'Dama (taurine) cattle of west Africa and many tropical zebu breeds are known to have greater tolerance to tick infestations than taurine breeds of temperate regions or origin (Latif et al. 1991; Mattioli et al. 1993; Rechav et al. 
1990). Thus, it is believed that tick resistance tends to be acquired with exposure (Latif et al. 1991). However, the report by Kerr et al. (1994) about evidence of a major gene for tick resistance in cattle and evidence from previous reports (Stear et al. 1984, 1990) began the earnest search for the gene or genes that control genetic resistance to tick infestations. Several reports today have associated alleles of genes of the BoLA system with various aspects of resistance/susceptibility to tick infections in cattle. Initial reports of associations came from Stear et al. (1984, 1990) who related BoLA class I alleles w6.1 and w7 to tick protection. In a preliminary study, Martinez et al. (2004) found putative associations between tick counts and alleles BoLA-DRB3. $2 * 10$ and $* 42$ and between warble counts and alleles $* 31$ and $* 42$ in cattle. In a more recent study, associations of BoLA alleles with lower tick number were found for alleles DRB3.2*18,*20, and *27 and a weaker association with allele $* 26$ (Martinez et al. 2006). From another perspective, dermal mast cells (DMC) are also thought to play a role in the host's resistance to tick infestations. Some reports have indicated that zebu breeds known to be highly resistant to ticks have twice the number of DMC than taurine cattle (of temperate origin) in $B$. microplus-parasitized skin biopsies (Moraes et al. 1992). $\mathrm{F}_{2}$ crossbred Gir $\times$ Holstein cattle were recently demonstrated to acquire resistance against $B$. microplus, probably the result of an increase in DMC (Engracia Filho et al. 2006). The massive migration of mast cells to the dermis during tick infestations is certainly under the control of yet unidentified genes. Given the above reports, it is clear that host immune genes play a major role in developing resistance to tick infestations. The major challenge now is to identify such genes and incorporate them into breeding programs for the generation of resistant livestock.

\section{Exploitation of genetic information and engineering in controlling livestock diseases}

The knowledge of the molecular genetic basis of livestock diseases has offered or is offering geneticists and breeders new avenues of tackling these diseases safely and cheaply. It should be noted that conventional methods of control such as change in management practices, culling, vaccinations, antibiotics, and other types of medications have succeeded to control many livestock diseases but with extra cost and associated problems, including antibiotic resistance and residues in the environment, and thus are a major cause of environmental and human health problems. A genetic means of control is one route of action that may prove beneficial to the animals, producers, and consumers. Genetic control of diseases that are under the control of single genes, if known, is easily achievable. For example, genetic tests (Table 1) exist for genotyping breeding animals for disease-causing mutations and the elimination of carriers from the breeding herd, thus limiting the spread of disease. Using this method, several of these diseases have been successfully controlled or eliminated from the herd. However, the causal mutations of many more diseases of cattle, goat, pig, and sheep that are under the control of single genes are yet to be determined and effectively controlled.

Diseases under multigenic control, which is complex, are not as easily determined and controlled as are those under unigenic control. Also, the interaction of many host genes is further compounded by pathogenic and environmental factors. This does not, however, make genetic control unattainable but calls for deeper knowledge of the interacting factors. With classical methods of breeding, disease traits with high heritability have been used successfully to reduce the incidence of some infectious diseases of farm animals. However, the heritability of most disease traits is very low and genetic control is not easily achievable through breeding. With the continued advancement in molecular genetic techniques and knowledge of the genome of farm animals, there is hope that molecular information can actually play a major role in effectively controlling livestock diseases. Available genome sequences and high-resolution molecular maps of some livestock species have opened new insights into the genetic bases of infectious diseases (McKay et al. 2007). Location of significant QTLs for some disease traits has actually led to the identification of responsible genes and causal SNPs and thus the possibility of disease control.

Apart from QTLs, genetic engineering through targeted disruption or addition of genes may be one avenue of control. Recently, Wall et al. (2005) produced transgenic cows secreting lysostaphin in their milk and further demonstrated that the transgenic cows have enhanced resistance to Staphylococcus aureus mastitis. In this case only enhanced resistance and not complete control because of the effects of other genes and the presence of other factors prompted Donovan et al. (2005) to think about introducing other genes or using other techniques like RNA interference to deal with more mastitis pathogens and also handle potential resistance issues. For prion diseases, Denning et al. (2001) and Perrier et al. (2002) indicated the possibility of a genetic engineering approach to control diseases through their observations in sheep and mice, respectively. Recently, Richt et al. (2006), by the method of sequential gene-targeting, produced cows deficient in normal cellular prion protein $\left(\operatorname{PrP}^{\mathrm{c}}\right)$; they were clinically, physiologically, histopathologically, immunologically, and reproductively normal thus opening an avenue for the production of cattle and products free of prion proteins. The application of genetic engineering in controlling livestock 
diseases is still at its infancy stage due to ethical issues and yet unidentified risk factors related to the technique.

\section{Implications of current findings and future perspectives on farm animal disease control}

Molecular markers have been used extensively to control diseases and to map QTLs that control resistance to certain diseases in farm animals, as exemplified in this review. However, much work is still required for many other diseases. To adequately control livestock diseases by exploiting genetic information, deeper knowledge of genome variations is required. As exemplified in humans, the near complete sequencing of human chromosomes has facilitated accurate characterization and assessment of all classes of genomic variation, and with the application of genome-wide scanning technologies (e.g., microarraybased comparative genomic hybridization, genome-wide SNP platforms), a new, previously unrecognized degrees of larger-sized genomic variations have been detected. These larger-sized variations include copy number variants $(>1$ $\mathrm{kb})$, large-sized inversions, insertions, deletions, and other complex rearrangements, most times not detectable by standard DNA sequencing procedures and cytogenetics (Feuk et al. 2006). It has been well established in studies of monogenic, oligogenetic, and complex diseases of humans that the study of such large-sized chromosomal rearrangements can be the fastest approach to identifying candidate disease loci (variants) and genes (Lugtenberg et al. 2006; Rosenberg et al. 2006; Vissers et al. 2005). Studies on such large-sized chromosomal rearrangements on livestock genomes could therefore facilitate detection of the genetic bases for some of those diseases (monogenic and complex) of livestock that still elude investigation. This implies that the genome sequences for these livestock species must first be available before such studies can be undertaken. For the genome sequences, including candidate genes and loci that are currently available, more detailed studies involving all sections of candidate genes and more genes in the vicinity of a QTL have to be carried out in order to identify candidate SNPs and copy number variants for more effective livestock disease control.

Furthermore, resistance or susceptibility to complex diseases of livestock (e.g., mastitis) pose great challenges to research efforts in terms of developing new methodologies for detection and integration of various genetic variants. Much research on disease-resistance phenotypes, conserved sequence homologies, and conserved functions has been done in human and mouse genes, and farm animals should be used as excellent models for investigation. Development and application of microassay-based techniques for genomics (DNA and mRNA), proteomics (protein), protein-protein interaction, and protein-DNA interaction and the role of small functional RNAs will no doubt facilitate our search for disease-resistance genes in farm animals. Furthermore, recent interest in and study of epigenetics in human medicine should greatly influence our research on disease resistance in farm animals. Epigenetic disorders give rise to several significant human diseases (Eggar et al. 2004). Epigenetic inheritance is the transmission of information from a one-cell or multicell organism to its descendants without that information being encoded in the nucleotide sequence of the gene. Epigenetic mechanisms such as DNA methylation, posttranslational modifications of histone proteins, remodeling of nucleosomes, and expression of small regulatory RNAs also contribute to the regulation of gene expression, determination of cell and tissue specificity, and assurance of inheritance of gene expression levels. All these could affect disease resistance. At this time, the epigenetic mechanisms underlining disease resistance in farm animals are unclear.

It is apparent that we are just at the beginning of understanding the contributions of genetics and epigenetics to diseases in farm animals. Despite many difficulties ahead of us, identification of the genes and mutations responsible for variation in disease resistance could greatly enhance the efficiency of breeding animals that possess innate disease resistance. Furthermore, it will provide new tools to facilitate research into the mechanisms of infection, possibly leading to additional pharmacologic and management approaches for the control of disease transmission. Finally, genetic control of animal diseases can reduce the costs associated with diseases, improve animal welfare, and provide healthy animal products to consumers, and it should be given more attention.

Generally, the less attention paid to research and control of animal diseases compared to diseases in humans is not a healthy trend of events. This is because an outbreak of a livestock disease can affect us directly or indirectly. The more recent outbreaks of BSE in livestock has lead to widespread loss of income, at both the farm and the government levels, and the Avian flu virus has led to the loss of hundreds of human lives. In the last century, losses of human lives due to livestock disease outbreaks were even more dramatic. Therefore, controlling livestock diseases should not be considered any less important.

\section{Conclusion}

Different types of changes that describe genetic variations of the genetic material have been implicated in one disease of livestock or another. These variations affect mRNA splicing patterns and result in alteration or complete 
elimination of protein function thereby leading to pathologic conditions in farm animals. However, information on genome variations involving large sections of the genetic material, including complex chromosomal rearrangements shown to explain some disease conditions in humans, is not available for livestock species. Knowledge of the genetic bases of some livestock diseases has led to control through breeding and is also opening new avenues of control through genetic engineering. For diseases under multigenic control, more research efforts have to be expended to fully understand the roles of controlling genes and develop effective control measures. Also, more effort has to be made in sequencing the genomes of the sheep, goat, and pig; this will provide the much needed baseline information for genetic studies into diseases. With increasing knowledge and advances in molecular biology, efforts at searching for and characterizing genes that control livestock diseases should intensify. The tool of genetic engineering should be fine tuned and safer alternatives to antibiotics and other therapeutic measures should be developed. Finally, a better understanding of all these factors could be better harnessed to effectively identify and control livestock diseases.

Acknowledgments Financial support was provided by McGill University's James McGill Professorship Program to X Zhao.

Open Access This article is distributed under the terms of the Creative Commons Attribution Noncommercial License which permits any noncommercial use, distribution, and reproduction in any medium, provided the original author(s) and source are credited.

\section{References}

Acutis PL, Bossers A, Priem J, Riina MV, Peletto S et al (2006) Identification of prion protein gene polymorphisms in goats from Italian scrapie outbreaks. J Gen Virol 87:1029-1033

Adams LG, Templeton JW (1998) Genetic resistance to bacterial diseases of animals. Rev Sci Tech 17:200-219

Agrimi U, Conte M, Morelli L, Di Bari MA, Di Guardo G et al (2003) Animal transmissible spongiform encephalopathies and genetics. Vet Res Commun 27(Suppl 1):31-38

Agyemang K (2005) Trypanotolerant livestock in the context of trypanosomiasis intervention strategies. PAAT Technical and Scientific Series 7. FAO, Rome

Ambrose N, Lloyd D, Maillard J-C (1999) Immune responses to Dermatophilus congolensis infections. Parasitol Today 15:295-300

Arango NA, Lovell-Badge R, Behringer RR (1999) Targeted mutagenesis of the endogenous mouse Mis gene promoter: in vivo definition of genetic pathways of vertebrate sexual development. Cell 99:409-419

Balbus N, Humeny A, Kashkevich K, Henz I, Fischer C et al (2005) DNA polymorphisms of the prion doppel gene region in four different German cattle breeds and cows tested positive for bovine spongiform encephalopathy. Mamm Genome 16:884-892

Baldwin CL, Parent M (2002) Fundamentals of host immune response against Brucella abortus: what the mouse model has revealed about control of infection. Vet Microbiol 90:367-382
Barthel R, Feng J, Piedrahita JA, McMurray DN, Templeton JA et al (2001) Stable transfection of bovine Nrampl gene into murine RAW264.7 cells: Effect on Brucella abortus survival. Infect Immun 69:3110-3119

Baylis M, Goldmann W (2004) The genetics of scrapie in sheep and goats. Curr Mol Med 4:385-396

Baylis M, Goldmann W, Houston F, Cairns D, Chong A et al (2002) Scrapie epidemic in a fully PrP-genotyped sheep flock. J Gen Virol 83:2907-2914

Beck CL, Fahlke C, George AL (1996) Molecular basis for decreased muscle chloride conductance in the myotonic goat. Proc Natl Acad Sci USA 93:11248-11252

Beever JE, Smit MA, Meyers SN, Hadfield TS, Bottema C et al (2006) A single-base change in the tyrosine kinase II domain of ovine FGFR3 causes hereditary chondrodysplasia in sheep. Anim Genet 37:66-71

Belt PBGM, Muileman IH, Schreuder BEC, Ruijter JBD, Gielkens ALJ et al (1995) Identification of five allelic variants of the sheep PrP gene and their association with natural scrapie. J Gen Virol 76:509-517

Benestad SL, Thu B, Bratberg B, Sarradin P, Schönheit J et al (2003) Cases of scrapie with unusual features in Norway and designation of a new type, Nor98. Vet Rec 153:202-208

Berg F, Gustafson U, Andersson L (2006) The uncoupling protein 1 gene $(U C P 1)$ is disrupted in the pig lineage: a genetic explanation for poor thermoregulation in piglets. PLoS Genet 2:1178-1181

Berthier D, Quere R, Thevenon S, Belemsaga D, Piquemal D et al (2003) Serial analysis of gene expression (SAGE) in bovine trypanotolerance: preliminary results. Genet Sel Evol 35(Suppl 1):35-47

Berthier D, Chantal I, Thévenon S, Marti J, Piquemal D et al (2006) Bovine transcriptome analysis by SAGE technology during an experimental Trypanosoma congolense infection. Ann N Y Acad Sci 1081:286-299

Billinis C, Panagiotidis CH, Psychas V, Argyroudis S, Nicolaou A et al (2002) Prion protein gene polymorphisms in natural goat scrapie. J Gen Virol 83:713-721

Bilstrom JA, Valberg SJ, Bernoco D, Mickelson JR (1998) Genetic test for myophosphorylase deficiency in Charolais cattle. Am J Vet Res 59:267-270

Bravo MJ, de Dios Colmenero J, Martín J, Alonson A, González AC (2006) Variation in the NRAMP1 gene does not affect susceptibility or protection in human brucellosis. Microb Infect 8:154-156

Campbell IL, Eddleston M, Kemper P, Oldstone MB, Hobbs MV (1994) Activation of cerebral cytokine gene expression and its correlation with onset of reactive astrocyte and acute-phase response gene expression in scrapie. J Virol 68:2383-2387

Cartegni L, Chew SL, Krainer AR (2002) Listening to silence and understanding nonsense: Exonic mutations that affect splicing. Nat Rev Genet 3:285-298

Cavanagh KT, Leipprandt JR, Jones MZ, Friderici K (1995) Molecular defect of caprine $\mathrm{N}$-acetylglucosamine-6-sulphatase deficiency. A single base substitution creates a stop codon in the $5^{\prime}$-region of the coding sequence. J Inherit Metab Dis 18:96

Chavez LS, Serda R, Choe S, Davidi L, Harmeyer J et al (2003) Molecular basis for pseudo vitamin D-deficiency rickets in the Hannover pig. J Nutr Biochem 14:378-385

Check E (2005) Human genome: Patchwork people. Nature 437: 1084-1086

Colige A, Sieron AL, Li SW, Schwarze U Petty E et al (1999) Human Ehlers-Danlos syndrome type VII C and bovine dermatosparaxis are caused by mutations in the Procollagen I N- Proteinase gene. Am J Hum Genet 65:308-317

Comincini S, Foti MG, Tranulis MA, Hills D, Di Guardo G et al (2001) Genomic organization, comparative analysis, and genetic polymorphisms of the bovine and ovine prion Doppel genes (PRND). Mamm Genome 12:729-733 
Courtin D, Argiro L, Jamonneau V, N'dri L, N'guessan P et al (2006) Interest of tumor necrosis factor-alpha $-308 \mathrm{G} / \mathrm{A}$ and interleukin-10 $-592 \mathrm{C} / \mathrm{A}$ polymorphisms in human African trypanosomiasis. Infect Genet Evol 6:123-129

Crisponi L, Deiana M, Loi A, Chiappe F, Uda M et al (2001) The putative forkhead transcription factor FOXL2 is mutated in blepharophimosis/epicanthus inversus syndrome. Nat Genet 27: 159-166

Croes EA, Alizadeh BZ, Bertoli-Avella AM, Rademaker T, VergeerDrop J et al (2004) Polymorphisms in the prion protein gene and in the doppel gene increase susceptibility for Creutzfeldt-Jakob disease. Eur J Hum Genet 12:389-394

Culbertson MR (1999) RNA surveillance. Unforeseen consequences for gene expression, inherited genetic disorders and cancer. Trends Genet 15:74-80

Cunningham C, Wilcockson DC, Boche D, Perry VH (2005) Comparison of inflammatory and acute-phase responses in the brain and peripheral organs of the ME7 model of prion disease. J Virol 79:5174-5184

da Mota AF, Martinez ML, Coutinho LL (2004) Genotyping BoLADRB3 alleles in Brazilian dairy cattle (Bos indicus) by temperature gradient gel electrophoresis (TGGE) and direct sequencing. Eur J Immunogenet 31:31-35

Dawson M, Hoinville LJ, Hosie BD, Hunter N (1998) Guidance on the use of PrP genotyping as an aid to the control of clinical scrapie. Vet Rec 142:623-625

Denning C, Burl S, Ainslie A, Bracken J, Dinnyes A et al (2001) Deletion of the $\alpha(1,3)$ galactosyl transferase $(G G T A 1)$ gene and the prion protein $(\operatorname{Pr} P)$ gene in sheep. Nat Biotech 19:559-562

Dennis JA, Healy PJ (1999) Definition of the mutation responsible for maple syrup urine disease in poll shorthorns and genotyping poll shorthorns and pool herefords for maple syrup urine disease alleles. Res Vet Sci 67:1-6

Dennis JA, Healy PJ, Beaudet al, Obrien WE (1989) Molecular definition of bovine argininosuccinate synthetase deficiency. Proc Natl Acad Sci USA 86:7947-7951

Dennis JA, Moran C, Healy PJ (2000) The bovine alpha-glucosidase gene: coding region, genomic structure, and mutations that cause bovine generalized glycogenosis. Mamm Genome 11:206-212

Detilleux JC (2002) Genetic factors affecting susceptibility of dairy cows to udder pathogens. Vet Immunol Immunopathol 88:103-110

Diaz C, Vitezica ZG, Rupp R, Andreoletti O, Elsen JM (2005) Polygenic variation and transmission factors involved in the resistance/susceptibility to scrapie in a Romanov flock. J Gen Virol 86:849-857

D'Ieteren GDM, Authié E, Wissocq N, Murray M (1998) Trypanotolerance, an option for sustainable livestock production in areas at risk from trypanosomosis. Rev Sci Technol 17:154-175

Dietz AB, Cohen ND, Timms L, Kehrli ME Jr (1997) Bovine lymphocyte antigen class II alleles as risk factors for high somatic cell counts in milk of lactating dairy cows. J Dairy Sci $80: 406-412$

Doherr MG (2006) Brief review on the epidemiology of transmissible spongiform encephalopathies (TSE). Vaccine 25:5619-5624

Dolan RB (1987) Genetics and trypanotolerance. Parasitol Today 3:137-143

Donovan DM, Kerr DE, Wall RJ (2005) Engineering disease resistant cattle. Transgenic Res 14:563-567

Drögenmüller C, Peters M, Pohlenz J, Distl O, Leeb T (2002) A single point mutation within the ED1 gene disrupts correct splicing at two different splice sites and leads to anhidrotic ectodermal dysplasia in cattle. J Mol Med 80:319-323

Duchesne A, Gautier M, Chadi S, Grohs C, Floriot S et al (2006) Identification of a doublet missense substitution in the bovine LRP4 gene as a candidate causal mutation for syndactyly in Holstein cattle. Genomics 88:610-621
Egger G, Liang G, Aparicio A, Jones PA (2004) Epigenetics in human disease and prospects for epigenetic therapy. Nature 429:457-463

Engracia Filho JR, Bechara GH, Teodoro RL (2006) Dermal mast cell counts in F2 Holstein $\times$ Gir crossbred cattle artificially infested with the tick Boophilus microplus (Acari: Ixodidae). Ann N Y Acad Sci 1081:476-478

Feuk L, Marshall CR, Wintle RF, Scherer SW (2006) Structural variants: changing the landscape of chromosomes and design of disease studies. Hum Mol Genet 15:R57-R66

Finocchiaro R, Portolano B, Damiani G, Caroli A, Budelli E et al (2003) The hairless (hr) gene is involved in the congenital hypotrichosis of Valle del Belice sheep. Genet Sel Evol 35:S147-S156

Ford CA, Stanfield AM, Spelman RJ, Smits B, Ankersmidt-Udy AE et al (2005) A mutation in bovine keratin 5 causing epidermolysis bullosa simplex, transmitted by a mosaic sire. J Invest Dermatol 124:1170-1176

Fujii J, Otsu K, Zorzato F, Deleon S, Khanna VK et al (1991) Identification of a mutation in porcine ryanodine receptor associated with malignant hyperthermia. Science 253:448-451

Geldermann H, Preuss S, Eckert Y, Han Y, Ollesch K (2003) Analysis of polymorphic microsatellites within the bovine and ovine prion protein (PRNP) genes. Anim Genet 34:283-289

Gibson JP (2001) Towards an understanding of genetic control of trypanotolerance. Newslett Integ Control Pathog Trypanosomes Vect 4:12-14

Goldmann W, Hunter N, Foster JD, Salbaum JM, Beyreuther K et al (1990) Two alleles of a neutral protein gene linked to scrapie in sheep. Proc Natl Acad Sci USA 87:2476-2480

Goldmann W, Hunter N, Martin T, Dawson M, Hope J (1991) Different forms of the bovine PrP gene have five or six copies of a short, G-C-rich element within the protein-coding exon. J Gen Virol 72:201-204

Goldmann W, Foster TMJ, Hughes S, Smith G, Hughes K et al (1996) Novel polymorphisms in the caprine PrP gene: a codon 142 mutation associated with scrapie incubation period. J Gen Virol 77:2885-2891

Goldmann W, Chong A, Foster J, Hope J Hunter N (1998) The shortest known prion protein gene allele occurs in goats, has only three octapeptide repeats and is non-pathogenic. J Gen Virol 79:3173-3176

Green BT, Heaton MP, Clawson ML, Laegreid WW (2006) Linkage disequilibrium across six prion gene regions spanning $20 \mathrm{kbp}$ in U.S. sheep. Mamm Genome 17:1121-1129

Grosse WM, Kappes SM, Laegreid WW, Keele JW, Chitko-McKown et al (1999) Single nucleotide polymorphism (snp) discovery and linkage mapping of bovine cytokine genes. Mamm Genome 10:1062-1069

Grunwald KAA, Schueler K, Uelmen PJ, Lipton BA, Kaiser M et al (1999) Identification of a novel Arg > Cys mutation in the LDL receptor that contributes to spontaneous hypercholesterolemia in pigs. J Lipid Res 40:475-485

Hanotte O, Ronin Y, Agaba M, Nilsson P, Gelhaus A et al (2003) Mapping of quantitative trait loci controlling trypanotolerance in a cross of tolerant West African N'Dama and susceptible East frican Boran cattle. Proc Natl Acad Sci USA 13:7443-7448

Hasler-Rapacz J, Ellegren H, Fridolfsson AK, Kirkpatrick B, Kirk S et al (1998) Identification of a mutation in the low density lipoprotein receptor gene associated with recessive familial hypercholesterolaemia in swine. Am J Med Genet 76:379-386

Healy PJ, Dennis JA (1994) Molecular heterogeneity for bovine maple syrup urine disease. Anim Genet 25:329-332

Healy PJ, Malmo J (1998) Roles for biochemical and polymerase chain reaction technologies in diagnosis and control of bovine alpha-mannosidosis. Aust Vet J 76:699-700

Healy PJ, Dennis JA, Windsor PA, Pierce KD, Schofield PR (2002) Genotyping cattle for inherited congenital myoclonus and maple syrup urine disease. Aust Vet J 80:695-697 
Hegasy GA, Manuelian T, Hogasen K, Jansen JH, Zipfel PF (2002) The molecular basis for hereditary porcine membranoproliferative glomerulonephritis type II - Point mutations in the factor $\mathrm{H}$ coding sequence block protein secretion. Am J Pathol 161:20272034

Hirano T, Hirotsune S, Sasaki S, Kikuchi T, Sugimoto Y (2002) A new deletion mutation in bovine claudin-16 (CL-16) deficiency and diagnosis. Anim Genet 33:118-122

Hoard HM, Leipprandt JR, Cavanagh KT, Truscott NK, Levene BAL et al (1998) Determination of genotypic frequency of caprine mucopolysaccharidosis IIID. J Vet Diagn Invest 10:181-183

Houweling PJ, Cavanagh JAL, Palmer DN, Frugier T, Mitchell NL et al (2006) Neuronal ceroid lipofuscinosis in Devon cattle is caused by a single base duplication (c.662dupG) in the bovine CLN5 gene. Biochim Biophys Acta 1762:890-897

How SJ, Lloyd DH (1988) Immunity to experimental dermatophilosis in rabbits and cattle following immunization with a live whole cell vaccine. Rev Elev Med Vet Pays Trop 41:139-146

Humeny A, Schiebel K, Seeber S, Becker CM (2002) Identification of polymorphisms within the bovine prion protein gene (Prnp) by DNA sequencing and genotyping by MALDI-TOF-MS. Neurogenetics 4:59-60

Hunter N, Goldmann W, Benson G, Foster JD, Hope J (1993) Swaledale sheep affected by natural scrapie differ significantly in PrP genotype frequencies from healthy sheep and those selected for reduced incidence of scrapie. J Gen Virol 74:1025-1031

Hunter N, Foster JD, Goldmann W, Stear MJ, Hope J et al (1996) Natural scrapie in a closed flock of Cheviot sheep occurs only in specific PrP genotypes. Arch Virol 141:809-824

Hunter N, Goldmann W, Foster JD, Cairns D, Smith G (1997a) Natural scrapie and PrP genotype: case-control studies in British sheep. Vet Rec 141:137-140

Hunter N, Moore L, Hosie B D, Dingwall W S, Greig A (1997b) Association between natural scrapie and PrP genotype in a flock of Suffolk sheep in Scotland. Vet Rec 140:59-63

Inaba M, Yawata A, Koshino I, Sato K, Takeuchi M et al (1996) Defective anion transport and marked spherocytosis with membrane instability caused by hereditary total deficiency of red cell band 3 in cattle due to a nonsense mutation. J Clin Invest 97:1804-1817

Jenkins MM, LeBoeuf RD, Ruth GR, Bloomer JR (1998) A novel stop codon mutation (X417L) of the ferrochelatase gene in bovine protoporphyria, a natural animal model of the human disease. Biochim Biophys Acta 1408:18-24

Jeong BH, Kim NH, Kim JI, Carp RI, Kim YS (2005) Polymorphisms at codons 56 and 174 of the prion-like protein gene (PRND) are not associated with sporadic Creutzfeldt-Jakob disease. J Hum Genet 50:311-314

Johnson EB, Steffen DJ, Lynch KW, Hertz J (2006) Defective splicing of Megf7/Lrp4, a regulator of distal limb development, in autosomal recessive mulefoot disease. Genomics 88:600-609

Kageyama S, Hirayama H, Moriyasu S, Inaba M, Ito D et al (2006) Genetic diagnosis of band 3 deficiency and sexing in bovine preimplantation embryos. J Vet Med Sci 68:319-323

Kanae Y, Endoh D, Nagahata H, Hayashi M (2005) A method for detecting complex vertebral malformation in Holstein calves using polymerase chain reaction-primer introduced restriction analysis. J Vet Diagn Invest 17:258-262

Kawakura K, Miyake YI, Murakami RK, Kondoh S, Hirata TI et al (1996) Deletion of the SRY region on the Y chromosome detected in bovine gonadal hypoplasia (XY female) by PCR. Cytogenet Cell Genet 72:183-184

Kelm SC, Detilleux JC, Freeman AE, Kehrli ME Jr, Dietz AB et al (1997) Genetic association between parameters of innate immunity and measures of mastitis in periparturient Holstein cattle. J Dairy Sci 80:1767-1775
Kerr RJ, Frisch JE, Kinghorn BP, Smith C, Gavora JS et al (1994) Evidence for a major gene for tick resistance in cattle. Proc. 5th World Congress on Genetics Applied to Livestock Production. Guelph, Ontario, Canada 7-12 August, 20:265-268

Khatar MS, Thomson PC, Tammen I, Raadsma HW (2004) Quantitative trait loci mapping in dairy cattle: review and metaanalysis. Gen Sel Evol 36:163-190

Koney EBM, Morrow AN, Heron ID, Ambrose MC, Scott GR (1994) Lymphocyte proliferative responses in relation to the occurrence of A. variegatum associated dermatophilosis. Vet Parasitol $55: 245-256$

Koopman P (1999) Sry and Sox9: mammalian testis-determining genes. Cell Mol Life Sci 55:839-856

Kraner S, Sieb JP, Thompson PN (2002) Congenital myasthenia in Brahman calves caused by homozygosity for CHRNE truncating mutation. Neurogenetics 4:87-91

Kristjanson PM, Swallow BM, Rowlands GJ, Kruska RL, de Leeuw PN (1999) Measuring the costs of African animal trypanosomosis: the potential benefits of control and returns to research. Agric Syst 59:79-98

Kumar N, Mitra A, Ganguly I, Singh R, Deb SM et al (2005) Lack of association of brucellosis resistance with (GT)13 microsatellite allele at 3'UTR of NRAMP1 gene in Indian zebu (Bos indicus) and crossbred (Bos indicus $\times$ Bos taurus ) cattle. Vet Microbiol 111:139-143

Kunieda M, Tsuji T, Abbasi AR, Khalaj M, Ikeda M et al (2005) An insertion mutation of the bovine F11 gene is responsible for factor XI deficiency in Japanese black cattle. Mamm Genome 16:383-389

Latif AA, Nokoe S, Punyua DK, Capstick PB (1991) Tick infestations on zebu cattle in Western Kenya: quantitative assessment of host resistance. J Med Entomol 28:122-126

Lee SH, Cho KK, Kang SK, Kim CW, Park HC et al (2002) Detection of pigs resistant to post-weaning diarrhoea, oedema disease and porcine stress syndrome by allele-specific polymerase chain reaction. Anim Genet 33:237-239

Leipprandt JR, Kraemer SA, Haithcock BE, Chen H, Dyme JL et al (1996) Caprine $\beta$-mannosidase: sequencing and characterization of the cDNA and identification of the molecular defect of caprine $\beta$-mannosidosis. Genomics 37:51-56

Leipprandt JR, Chen H, Horvath JE, Qiao XT, Jones MZ (1999) Identification of a bovine $\beta$-mannosidosis mutation and detection of two $\beta$-mannosidase pseudogenes. Mamm Genome 10:11371141

Leroy P, Marchot P (1987) The resistance to dermatophilosis of Dinka cattle breed, Dinka crossbred and Boran, Friesian, Jersey, Sahiwal crossbreds. Ann Rech Vét 18:107-109

Leyva-Baca I, Schenkel F, Sharma BS, Jansen GB, Karrow NA (2007) Identification of single nucleotide polymorphisms in the bovine CCL2, IL8, CCR2 and IL8RA genes and their association with health and production in Canadian Holsetains. Anim Genet 38: $198-202$

Lloyd SE, Onwuazor ON, Beck JA, Mallinson G, Farrall M et al (2001) Identification of multiple quantitative trait loci linked to prion disease incubation period in mice. Proc Natl Acad Sci USA 98:6279-6283

Lugtenberg D, de Brouwer AP, Kleefstra T, Oudakker AR, Frints SG et al (2006) Chromosomal copy number changes in patients with non-syndromic $\mathrm{X}$-linked mental retardation detected by array CGH. J Med Genet 43:362-370

Luhrs T, Riek R, Guntert P, Wuthrich K (2003) NMR structure of the human doppel protein. J Mol Biol 326:1549-1557

Lühken G, Zieleniewicz D, Brandt HR, Buschmann A, Groschul MH et al (2007) Microsatellites MCMA53 and MCMA16 on OAR15 are associated with susceptibility to atypical scrapie. Anim Genet 38:88-89 
Lundén A, Marklund S, Gustafsson V, Andersson L (2002) A nonsense mutation in the FMO3 gene underlies fishy off-flavor in cow's milk. Genome Res 12:1885-1888

Maciulis A, Hunter N, Wang S, Goldmann W, Hope J et al (1992) Polymorphisms of a scrapie-associated fibril protein $(\mathrm{PrP})$ gene and their association with susceptibility to experimentally induced scrapie in cheviot sheep in the United States. Am J Vet Res 53:1957-1960

Maillard JC, Kemp SJ, Levéziel H, Teale AJ, Quéval R (1989) Le complexe majeur d'histocompatibilité de bovins Ouest africains. Typage d'antigènes lymphocytaires (BoLA) de taurins Baoulé (Bos taurus) et de zébus Soudaniens (Bos indicus) du Burkina Faso (Afrique Occidentale). Rev Elev Méd Vét Pays Trop 42:275-281

Maillard JC, Martinez D, Bensaid A (1996) An amino acid sequence encoded by the exon 2 of the BoLA DRB3 gene associated with a BoLA class 1 specificity constitutes a likely genetic marker of resistance to dermatophilosis in Brahman zebu cattle in Martinique (FWI). Ann N Y Acad Sci 791:185-197

Maillard JC, Renard C, Chardon P, Chantal I, Bensaid A (1999) Characterization of 18 new BoLA-DRB3 alleles in zebu Brahman cattle. Anim Genet 30:200-203

Maillard JC, Chantal I, Berthier D (2001) Sequencing of four new $B o L A-D R B 3$ and six new BoLA-DQB alleles. Anim Genet 32:44-46

Maillard JC, Chantal I, Berthier D, Thevenon S, Sidibé I et al (2002) Molecular immunogenetics in susceptibility to bovine dermatophilosis: a candidate gene approach and a concrete field application. Ann N Y Acad Sci 969:92-96

Maillard JC, Berthier D, Chantal I, Thevenon S, Sidibé I et al (2003) Selection assisted by BoLA-DR/DQ haplotype against susceptibility to bovine dermatophilosis. Genet Sel Evol 35(Suppl 1):S193-S200

Maillard JC, Berthier D, Thevenon S, Quere R, Piquemal D et al (2004) Use of the serial analysis of gene expression (SAGE) method in veterinary research: a concrete application in the study of the bovine trypanotolerance genetic control. Ann N Y Acad Sci 1026:171-182

Maillard JC, Berthier D, Thevenon S, Piquemal D, Chantal I et al (2005) Efficiency and limits of the serial analysis of gene expression (SAGE) method: discussions based on first results in bovine trypanotolerance. Vet Immunol Immunopathol 108:59-69

Mallard BA, Leslie KE, Dekkers JCM, Hedge R, Bauman M et al (1995) Differences in bovine lymphocyte antigen associations between immune responsiveness and risk of disease following intramammary infection with Staphylococcus aureus. J Dairy Sci 78:1937-1944

Manolakou K, Beaton J, McConnell I, Farquar C, Manson J et al (2001) Genetic and environmental factors modify bovine spongiform encephalopathy incubation period in mice. Proc Natl Acad Sci USA 98:7402-7407

Marcos-Carcavilla A, Calvo JH, González C, Moazami-Goudarzi K, Laurent $P$ et al (2007) IL-1 family members as candidate genes modulating scrapie susceptibility in sheep: localization, partial characterization, and expression. Mamm Genome 18:53-63

Marron BM, Robinson JL, Gentry PA, Beever JE (2004) Identification of a mutation associated with factor XI deficiency in Holstein cattle. Anim Genet 35:454-456

Martinez D, Aumont G, Moutoussamy M, Gabriel D, Tatareau AH et al (1993) Epidemiological studies on dermatophilosis in the Caribbean. Rev Elev Med Vet Pays Trop 46:323-327

Martinez ML, Silva MVGB, Machado MA, Nascimento CS et al (2004) Associaçã do gene candidato BoLA-DRB3.2 con resistência a ectoparasitos em bovinos. Proceedings of the 41 Reunião Anual da Sociedade Brasileira de Zootecnia, Camp Grande, MS, Brazil

Martinez ML, Machado MA, Nascimento CS, Silva MVGB, Teodoro RL et al (2006) Association of BoLA-DRB3.2 alleles and tick
(Boophilus microplus) resistance in cattle. Genet Mol Biol 5:513-524

Mattioli RC, Bah M, Faye J, Kora S, Cassama M (1993) A comparison of field tick infestation on N'Dama, Zebu and N'Dama $\times$ Zebu crossbred cattle. Vet Parasitol 47:139-148

Mattioli RC, Bah M, Kora S, Cassama M, Clifford DJ (1995) Susceptibility to different tick genera in Gambian N'Dama and Gobra Zebu cattle exposed to naturally occurring tick infestations. Trop Anim Health Prod 27:95-105

McKay SD, Schnabel RD, Murdoch BM, Aerts J, Gill CA et al (2007) Construction of bovine whole-genome radiation hybrid and linkage maps using high-throughput genotyping. Anim Genet 38:120-125

Mejdell CM, Lie O, Solbu H, Arnet EF, Spooner RL (1994) Association of major histocompatibility complex antigens (BoLA-A) with AI bull progeny test results for mastitis, ketosis and fertility in Norwegian cattle. Anim Genet 25:99-104

Montaraz JA, Winter AJ (1986) Comparison of living and nonliving vaccines for Brucella abortus in BALB/c mice. Infect Immun 5:245-251

Moore RC, Lee IY, Silverman GL, Harrison PM, Strome R et al (1999) Ataxia in prion protein (PrP)-deficient mice is associated with upregulation of the novel PrP-like protein doppel. J Mol Biol 292:797-817

Moraes FR, Moraes JRE, Costa AJ et al (1992) A comparative study of lessions caused by different parasitic stages of Boophilus microplus (Canestrini) in the skins of naturally infested taurine and zebuine hosts. The correlation of tick resistance with mast cell counts in the host's skin. Braz J Vet Res Anim Sci 29:378-383

Moreno CR, Cosseddu GM, Andreoletti O, Schibler L, Roig A et al (2003a) Identification of quantitative trait loci (QTL) modulating prion incubation period in sheep. Proceedings of the International Workshop on Major Genes and QTL in Sheep and Goat, Toulouse, France, 8-11 December 2002, Communication No. 2-27

Moreno CR, Lantier F, Lantier I, Sarradin P, Elsen JM (2003b) Detection of new quantitative trait loci for susceptibility to transmissible spongiform encephalopathies in mice. Genetics 165:2085-2091

Morrow AN, Compton EAE (1991) The occurrence of streptothricosis and its association with $A$. variegatum ticks in St Lucia. J Vet Med Ser B 38:635-638

Moum T, Olsaker I, Hopp P, Moldal T, Valheim M et al (2005) Polymorphisms at codons 141 and 154 in the ovine prion protein gene are associated with scrapie Nor98 cases. J Gen Virol $86: 231-235$

Mukhopadhyaya PN, Jha M, Muraleedharan P, Gupta RR, Rathod RN et al (2006) Simulation of normal, carrier and affected controls for large-scale genotyping of cattle for factor XI deficiency. Genet Mol Res 5:323-332

Murray M, Stear MJ, Trail JCM, D’Ieteren GDM, Agyemang K et al (1991) Trypanosomiasis in cattle: prospects for control. In: Owen JB, Axford RFE (eds) Breeding for Disease Resistance in Farm Animals, 1st ed. CABI Publishing, Wallingford, England, pp 195-216

Naessens J (2006) Bovine trypanotolerance: a natural ability to prevent severe anaemia and haemophagocytic syndrome? Int $\mathrm{J}$ Parasitol 36:521-528

Naessens J, Leak SGA, Kennedy DJ, Kemp S, Teale AJ (2003) Responses of haemopoietic chimaera twin cattle from susceptible and tolerant genetic backgrounds to experimental infection with Trypanosoma congolense. Vet Parasitol 111:125-142

Neibergs HL, Ryan AM, Womack JE, Spooner RL, Williams JL (1994) Polymorphism analysis of the prion gene in BSE affected and unaffected cattle. Anim Genet 25:313-317

Nezamzadeh R, Seubert A, Pohlenz J, Brenig B (2005) Identification of a mutation in the ovine uroporphyrinogen decarboxylase 
(UROD) gene associated with a type of porphyria. Anim Genet 36:297-302

Orge L, Galo A, Machado C, Lima C, Ochoa C et al (2004) Identification of putative atypical scrapie in sheep in Portugal. $\mathrm{J}$ Gen Virol 85:3487-3491

Ohba Y, Kitagawa H, Kitoh K, Sasaki Y, Takami M et al (2000) A deletion of the paracellin-1 gene is responsible for renal tubular dysplasia in cattle. Genomics 68:229-236

Paape MJ, Bannerman DD, Zhao X, Lee J-W (2003) The bovine neutrophil: structure and function in blood and milk. Vet Res 34:597-627

Pailhoux E, Vigier B, Chaffaux S, Servel N, Taourit S et al (2001) A $11.7-\mathrm{kb}$ deletion triggers intersexuality and polledness in goats. Nat Genet 29:453-458

Pailhoux E, Vigier B, Schibler L, Cribiu EP, Cotinot C et al (2005) Positional cloning of the PIS mutation in goats and its impact on understanding mammalian sex-differentiation. Genet Sel Evol 37(Suppl 1):S55-S64

Paixão TA, Ferreira C, Borges ÁM, Oliveira DAA, Lage AP et al (2006) Frequency of bovine Nramp1 (Slcla1) alleles in Holstein and Zebu breeds. Vet Immunol Immunopathol 109:37-42

Paixão TA, Poester FP, Carvalho Neta AV, Borges ÁM, Lage AP et al (2007) NRAMP1 3' untranslated region polymorphisms are not associated with natural resistance to Brucella abortus in cattle. Infect Immun 75:2493-2499

Perrier V, Kaneko K, Safar J, Vergara J, Tremblay P et al (2002) Dominant-negative inhibition of prion replication in transgenic mice. Proc Natl Acad Sci USA 99:13079-13084

Pierce KD, Handford CA, Morris R, Vafa B, Dennis JA et al (2001) A nonsense mutation in the $\alpha 1$ subunit of the inhibitory glycine receptor associated with bovine myoclonus. Mol Cell Neurosci 17:354-365

Priola SA, Vorberg I (2004) Molecular aspects of disease pathogenesis in the transmissible spongiform encephalopathies. Methods Mol Biol 268:517-540

Queval R, Bambara L (1984) Le polymorphisme de l'albumine dans la race Baoulé et une population de zébus de type soudanien. Rev Elev Méd Vét Pays Trop 37:288-296

Queval R, Petit JP(1982) Polymorphisme biochimique de l'hémoglobine de populations bovines trypanosensibles, trypanotolérantes et de leurs croisements dans l'Ouest africain. Rev Elev Méd Vét Pays Trop 35:137-146

Qureshi T, Templeton JW, Adams LG (1996) Intracellular survival of Brucella abortus, Mycobacterium bovis (BCG). Salmonella dublin and Salmonella typhimurium in macrophages from cattle genetically resistant to Brucella abortus. Vet Immunol Immunopathol 50:55-66

Rambeaud M, Pighetti GM (2005) Impaired neutrophil migration associated with specific bovine CXCR2 genotpyes. Infect Immun 73:4955-4959

Rambeaud M, Clift R, Pighetti GM (2006) Association of a bovine CXCR2 gene polymorphism with neutrophil survival and killing ability. Vet Immunol Immunopathol 111:231-238

Rantamaki T, Kaitila I, Syvanen AC, Lukka M, Peltonen L (1999) Recurrence of Marfan Syndrome as a result of parental germ-line mosaicism for an FBN1 mutation. Am J Hum Genet 64:993-1001

Razafindraibe H, Raliniaina M, Maillard JC, Rakotondravao (2006) Renitelo cattle dermatophilosis and PCR-RFLP analysis of MHC gene. Ann N Y Acad Sci 1081:489-491

Rechav Y, Dauth J, Els DA (1990) Resistance of Brahman and Simmentaler cattle to Southern African ticks. Onderstepoort J Vet Res 57:7-12

Richt JA, Kasinathan P, Hamir AN, Castilla J, Sathiyaseelan T et al (2006) Production of cattle lacking prion protein. Nat Biotechnol $25: 132-138$
Ricketts MH, Simons MJ, Parma J, Mercken L, Dong Q et al (1987) A nonsense mutation causes hereditary goiter in the Afrikander cattle and unmasks alternative splicing of thyroglobulin transcripts. Proc Natl Acad Sci USA 84:3181-3184

Rosenberg C, Knijnenburg J, Bakker E, Vianna-Morgante AM, Sloos $\mathrm{W}$ et al (2006) Array-CGH detection of micro-rearrangements in mentally retarded individuals: clinical significance of imbalances present both in affected children and normal parents. J Med Genet 43:180-186

Rothschild MF, Skow L, Lamont SJ (2000) The major histocompatibility complex and its role in disease resistance and immune responsiveness. In: Axford RFE, Bishop SC, Nicholas FW, Owen JB (eds) Breeding for Disease Resistance in Farm Animals. CABI Publishing, Wallingford, England, pp 73-105

Rupp R, Boichard D (2003) Genetics of resistance to mastitis in dairy cattle. Vet Res 34:671-688

Rupp R, Hernandez A, Mallard BA (2007) Association of bovine leukocyte antigen (BoLA) DRB3.2 with immune response, mastitis and production and type traits in Canadian Holsteins. J Dairy Sci 90:1029-1038

Ryu S, Park YK, Bai GH, Kim SJ, Park SN et al (2000) $3^{\prime}$ UTR polymorphisms in the NRAMP1 gene are associated with susceptibility to tuberculosis in Koreans. Int $\mathrm{J}$ Tuberc Lung Dis 4:577-580

Sander P, Hamann H, Pfeiffer I, Wemheuer W, Brenig B et al (2004) Analysis of sequence variability of the bovine prion protein gene (PRNP) in German cattle breeds. Neurogenetics 5:19-25

Schmid R, Mahler R (1959) Chronic progressive myopathy with myoglobinuria: demonstration of a glycogenolytic defect in the muscle. J Clin Invest 38:2044-2058

Schmutz SM, Berryere TG, Ciobanu DC, Mileham AJ, Schmidtz BH et al (2004) A form of albinism in cattle is caused by a tyrosinase frameshift mutation. Mamm Genome 15:62-67

Schwenger B, Schöber S, Simon D (1993) DUMPS cattle carry a point mutation in the uridine monophosphate synthase gene. Genomics 16:241-244

Scott MR, Will R, Ironside J, Nguyen HO, Tremblay P et al (1999) Compelling transgenetic evidence for transmission of bovine spongiform encephalopathy prions to humans. Proc Natl Acad Sci USA 96:15137-15142

Seeliger F, Drögenmüller C, Tegtmeier P, Baumgärtner W, Distl O et al (2005) Ectodysplasin-1 deficiency in German Holstein bull associated with loss of respiratory mucous glands and chronic rhinotracheities. J Comp Pathol 132:346-349

Sharif S, Mallard BA, Wilkie BN, Sargeant JM, Scott HM et al (1998) Associations of bovine major histocompatibility complex DRB3 (BoLA-DRB3) alleles with occurrence of disease and milk somatic cell score in Canadian dairy cattle. Anim Genet 29:185-193

Sharif S, Mallard BA, Sargeant JM (2000) Presence of glutamine at position 74 of pocket 4 in the BoLA-DR antigen binding groove is associated with occurrence of clinical mastitis caused by Staphylococcus species. Vet Immunol Immunopathol 76:231-238

Shuster DE, Kehrli ME, Ackermann MR Jr, Gilbert RO (1992) Identification and prevalence of a genetic defect that causes leukocyte adhesion deficiency in Holstein cattle. Proc Natl Acad Sci USA 89:9225-9229

Singleton AC, Mitchell AL, Byers PH, Potter KA, Pace JM (2005) Bovine model of Marfan syndrome results from an amino acid change (c.3598G $>$ A, p.E1200K) in a calcium-binding epidermal growth factor-like domain of fibrillin-1. Hum Mutat 25:348-352

Sironen A, Thomsen B, Andersson M, Ahola V, Vilkki J (2006) An intronic insertion in KPL2 results in aberrant splicing and causes the immotile short-tail sperm defect in the pig. Proc Natl Acad Sci USA 103:5006-5011 
Stear MJ, Newman MJ, Nicholas FW, Brown SC, Holroyd RG (1984) Tick resistance and the major histocompatibility system. Aust J Exp Biol Med Sci 62:47-52

Stear MJ, Hetzel DJS, Brown SC, Gershwin LJ, Mackinnon MJ et al (1990) The relationships among ecto- and endoparasite levels, class I antigens of the bovine major histocompatibility system, immunoglobulin E levels and weight gain. Vet Parasitol 34:303-321

Sugimoto M, Furuoka H, Sugimoto Y (2003) Deletion of one of the duplicated HSP70 genes causes hereditary myopathy of diaphragmatic muscles in Holstein-Friesian cattle. Anim Genet 34:191-197

Sugimoto M, Fujikawa A, Womack JE, Sugimoto Y (2006) Evidence that bovine forebrain embryonic zinc finger-like gene influences immune response associated with mastitis resistance. Proc Natl Acad Sci USA 103:6454-6459

Tajima M, Miyake S, Takehana K, Kobayashi A, Yamato O et al (1999) Gene defect of dermatan sulfate proteoglycan of cattle affected with a variant form of Ehlers-Danlos syndrome. J Vet Intern Med 13:202-205

Tan P, Allen JG, Wilton SD, Akkari PA, Huxtable CR et al (1997) A splice-site muytation causing ovine McArdle's disease. Neuromuscular Disord 7:336-342

Templeton JW, Estes DM, Price RE, Smith R III, Adams LG (1990) Immunogenetics of natural resistance to bovine brucellosis. In: Teal A (ed) Proceedings of the 4th World Congress of Genetics Applied to Livestock Production. University of Edinburgh, Edinburgh, pp 396-399

Thompson PN, van der Werf JHJ, Heesterbeek JAP, van Arendonk JAM (2007) The CHRNE 470del20 mutation causing cogenital myasthenic syndrome in South African Brahman cattle: Prevalence, origin, and association with performance traits. J Anim Sci 85:604-609

Thomsen B, Horn P, Panitz F, Bendixen E, Petersen AH et al (2006) A missense mutation in the bovine $S L C 35 A 3$ gene, encoding a UDP-N-acetylglucosamine transporter, causes complex vertebral malformation. Genome Res 16:97-105

Tollersrud OK, Berg T, Healy P, Evjen G, Ramachandran U et al (1997) Purification of bovine lysosomal $\alpha$-mannosidase, characterization of its gene and determination of two mutations that cause $\alpha$-mannosidosis. Eur J Biochem 246:410-419

Trail JCM, d'Ieteren GDM, Feron A, Kakiese O, Mulungo M et al (1991) Effect of trypanosome infection, control of parasitaemia and control of anaemia development on productivity of N'Dama cattle. Acta Trop 48:37-45

Trail JCM, d'Ieteren GDM, Viviani P, Yangari G, Nantulya VM (1992) Relationships between trypanosome infection measured by antigen detection enzyme immunoassays, anaemia and growth in trypanotolerant N'Dama cattle. Vet Parasitol 42:213-223

Trail JCM, Wissocq N, d'Ieteren GDM, Kakiese O, Murray M (1994) Quantitative phenotyping of N'Dama cattle for aspects of trypanotolerance under field tsetse challenge. Vet Parasitol 55:185-195

Tsuijino S, Shanske S, Valberg SJ, Cardinet GH, Smith BP et al (1996) Cloning of bovine muscle glycogen phosphorylase cDNA and identification of a mutation in cattle with myophosphorylase deficiency, an animal model for McArdle's disease. Neuromuscular Disord 6:19-26

Tyynelä J, Sohar I, Sleat DE, Gin RM, Donnelly RJ et al (2000) A mutation in the ovine cathepsin D gene causes a congenital lysosomal storage disease with profound neurodegeneration. EMBO J 19:2786-2792

Vaccari G, Di Bari MA, Morelli L, Nonno R, Chiappini B et al (2006) Identification of an allelic variant of the goat PrP gene associated with resistance to scrapie. J Gen Virol 87:1395-1402

van Ommen GJB, Sterk A, Mercken LOY, Arnberg AC, Baas F et al (1989) Studies on the structures of the normal and abnormal goat thyroglobulin genes. Biochimie 71:211-221

van Tassel CP, Ashwell MS, Sonstegard TS (2000) Detection of putative loci affecting milk, health, and conformation traits in a US Holstein population using 105 microsatellite markers. J Dairy Sci 83:1865-1872

Veenboer GJM, de Vijlder JJM (1993) Molecular basis of the thyroglobulin synthesis defect in Dutch goats. Endocrinology 132:377-381

Vidal SM, Malo D, Vogan K, Skamene E, Gros P (1993) Natural resistance to infection with intracellular parasites: isolation of a candidate for $B c g$. Cell 73:469-485

Vissers LE, Veltman JA, van Kessel AG, Brunner HG (2005) Identification of disease genes by whole genome CGH arrays. Hum Mol Genet 14:R215-R223

Wall RJ, Powell AM, Paape MJ, Kerr DE, Bannerman DD et al (2005) Genetically enhanced cows resist intramammary Staphylococcus aureus infection. Nat Biotechnol 23:445-451

Wyckoff JH III (2002) Bovine T lymphocyte responses to Brucella abortus. Vet Microbiol 90:395-415

Youngerman SM, Saxton AM, Oliver SP, Pighetti GM (2004) Association of CXCR2 polymorphisms with subclinical and clinical mastitis in dairy cattle. J Dairy Sci 87:2442-2448

Yuzbasyan-Gurkan V, Bartlett E (2006) Identification of a unique splice site variant in SLC39A4 in bovine hereditary zinc deficiency, lethal trait A46: an animal model of acrodermatitis enteropathica. Genomics 88:521-526

Zhang B, Healy PJ, Crabb DW, Harris RA (1990) Premature translation termination of the pre E1 $\alpha$ subunit of the branced chain $\alpha$-keto acid dehydrogenase as a cause of Maple Syrup Urine Disease in Polled Hereford calves. J Biol Chem 265:2425-2427

Zhang C, De Koning DJ, Hernandez-Sanchez J, Haley CS, Williams JL et al (2004) Mapping of multiple quantitative trait loci affecting bovine spongiform encephalopathy. Genetics 167:1863-1872 